\title{
Fossil mammals of Caladenia Cave, northern Swan Coastal Plain, south-western Australia
}

\author{
Kailah M. Thorn ${ }^{*}$, Robin Roe ${ }^{2}$, Alexander Baynes ${ }^{3}$, \\ Raymond P. Hart ${ }^{2} \uparrow$, Kenneth A. Lance ${ }^{2}$, Duncan Merrilees ${ }^{2} \dagger$, \\ Jennifer K. Porter ${ }^{2}$ and Sandra Sofoulis ${ }^{2}$ \\ 1 School of Animal Biology, University of Western Australia, Crawley, Western Australia 6009, \\ Australia. Present address: College of Science and Engineering, Flinders University, GPO Box 2100, \\ Adelaide, South Australia 5001, Australia. \\ 2 Department of Palaeontology, Western Australian Museum, Locked Bag 49, Welshpool DC, \\ Western Australia 6986, Australia. \\ ${ }^{3}$ Department of Earth and Planetary Sciences, Western Australian Museum, Locked Bag 49, \\ Welshpool DC, Western Australia 6986, Australia. \\ $\dagger$ Deceased \\ * Corresponding author: kailah.thorn@gmail.com
}

\begin{abstract}
Quaternary palaeoecological research in Western Australia has been focussed primarily around Perth and the extreme south-west, with very little work conducted to the north between $29^{\circ}$ and $32^{\circ} \mathrm{S}$. Using fossil remains excavated in the 1970s from Caladenia Cave in the East Moore cave area of the northern Swan Coastal Plain, we sought evidence of compositional change in the regional mammal fauna from the mid-Holocene to the present. Loss of Phascogale calura, Perameles bougainville and Lagorchestes hirsutus, species characteristic of semi-arid and arid regions, suggests an increase in rainfall from around $4700 \mathrm{cal}$. BP. A change to a smaller sieve mesh aperture in the deepest levels of the excavation caused differential recovery which constrained the extent to which ecological inferences could be made. This bias notwithstanding, the Caladenia Cave assemblage suggests major community changes did not characterise the late Holocene, indicating resilience to the impacts of environmental changes prior to European settlement.
\end{abstract}

KEYWORDS: Holocene, Palaeoecology, Differential Recovery, EM-17

\section{INTRODUCTION}

Western Australian vertebrate palaeontology was focussed primarily on the documentation of megafaunal remains until the visit in the mid 1950s by American Fulbright Scholar Ernest L. Lundelius Jr, who initiated the palaeoecological investigation of small mammal assemblages (Lundelius 1957, 1960). Many Western Australian Quaternary cave deposits provide evidence of climatically-driven changes in Late Quaternary species distributions and abundances (Lundelius 1960; Merrilees 1967). Quantitative analyses of small mammal accumulations can provide a more accurate representation of the original communities surrounding a deposit than historical records (Baynes 1979; Lundelius 2006).

Previous studies in south-western Australia have interpreted patterns in climate change from presence/ absence and abundance of 'proxy' species over time (Baynes et al. 1976; Balme et al. 1978; Prideaux et al. 2010). Species such as Perameles bougainville, Bettongia lesueur and Petrogale lateralis are considered indicative of a drier, non-forest environment (Merrilees 1967), whereas Setonix brachyurus is considered a proxy for a dense understorey of tall karri forest that requires an annual rainfall of 1000-1200 mm (Baynes et al. 1976; Dortch 2004; Prideaux et al. 2010). These examples demonstrate that changes in climate can be inferred from change in the presence/absence of species characteristic of ecosystems adapted to higher or lower rainfall (see Dortch 2004).

There are very few early historic records of mammals of the northern Swan Coastal Plain, most of the native populations having been devastated by the introduction of cats, foxes and rabbits (see Kitchener et al. 1978 and Wilson et al. 2012). Consequently, fossil assemblages offer the best archives of fauna that originally occupied the region. The study of palaeontological assemblages can generate data that may help model the impacts that future anthropogenic climate change may have 
on endemic fauna. Similar work in northern Western Australia and South Australia using Holocene cave sites has been used to extend species records for conservation research in national parks and suggested species rehabilitation sites based on palaeo-distributions (Baynes and McDowell 2010; McDowell et al. 2012). Our investigation of the Caladenia Cave fossil mammal assemblage in 2013 tracked the presence/absence and relative abundances of mammal species through time to detect correlations with extrinsic factors such as climate change. At conception, the investigation was purely exploratory and no hypothesis could be proposed about the presence of particular fauna, or any palaeoecological signals within the resulting data.

\section{SITE}

Caladenia Cave (EM-17) is located between the Moore River mouth at Guilderton and Gingin Scarp on the Swan Coastal Plain (Figure 1). It is one of 19 caves known in the East Moore cave area and the only cave excavated for vertebrate remains (Susac 2007). Caladenia Cave is an inclined fissure cave that developed in the Tamala Limestone, a Pleistocene aeolian calcarenite (Bastian 1964).

The discovery of vertebrate remains and their subsequent excavation in Caladenia Cave by amateur palaeontologist Robin Roe in the early 1970s provides the only existing late Quaternary record in the lower Moore River catchment. As Roe's trench was backfilled its precise location could not be determined. However, based on sketches in Roe's notebook (Roe 1971) we were able to determine its approximate location (Figures 2-3).

\section{MATERIALS AND METHODS}

\section{SOURCING THE MATERIAL}

The fieldwork and excavation conducted by Robin Roe (1970-1975) was initially supervised by Duncan Merrilees (1970-1972), Curator of Palaeontology at the Western Australian Museum, and later assisted by Sandra Sofoulis (1972 until completion). During excavation, Roe and Sofoulis noticed a deterioration of material condition at greater depths and changed the sieve grade to mitigate loss of small specimens (Roe 1974). They used sieves with $3 \mathrm{~mm}$ mesh aperture to sieve the sediment from the surface of the deposit down to the base of 'Stone Heap End' and the test pit. For 'Wall End' they changed to a sieve with a $1 \mathrm{~mm}$ mesh from $1.48 \mathrm{~m}$ to $2.54 \mathrm{~m}$ (Groups L to R). Rock and other materials not relevant to the investigation were removed by Roe after sieving. The screen residues were sorted and preliminarily identified by R. P. Hart, K. A. Lance, D. Merrilees and J. K. Porter in the 1970s. Bone specimens were placed in labelled 6 or 12 dram vials and stored by excavation spit. Bird, reptile, fish and archaeological materials were not further investigated in this study.

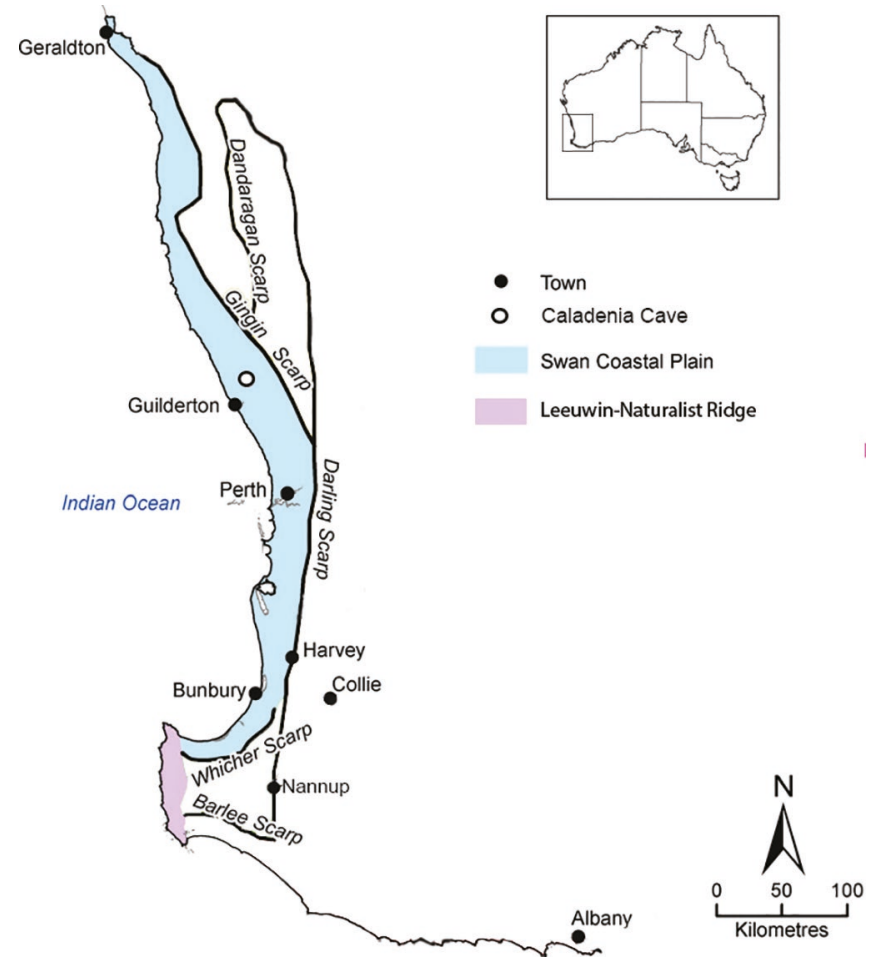

FIGURE 1 Map of the geomorphological features of the southern west coastal region of Australia, showing the location of Caladenia Cave. Image adapted from Barron et al. (2012).

Taphonomic analyses were based on the unidentified bulk-bone fragments, chosen randomly from each data Group (see Table 1) and examined for breakage and digestion damage. Evidence for digestion was recorded as an estimated percentage of the bone surface showing digestive erosion. Breakage was recorded as the percentage remaining of the original complete bone. Material was divided into two faunal size classes (mean adult body weight $>250 \mathrm{~g}$ and $<250 \mathrm{~g}$ ) to ensure that sieve size bias could be removed from at least the larger species data set. The data were subjected to a ShapiroWilk test for normality within each size class. Paired $t$-tests were then conducted in PAST to determine if the two size classes were taphonomically different from one another.

Caladenia Cave was surveyed and mapped in 2013 at grade 44 of the Australian Speleological Federation survey and map standards (Anderson 1997), with width and height measurements recorded every $1 \mathrm{~m}$ along the $\mathrm{N}-\mathrm{S}$ and E-W sections, accurate to the nearest $0.1 \mathrm{~m}$.

\section{CHRONOLOGY}

Charcoal samples were collected from most spits, wrapped in foil, labelled and bagged by Roe at the time of excavation. In 2013 samples for dating were chosen based on significant fauna-related events, such as the disappearance of species from the assemblage, or at major stratigraphic boundaries, and at the base and close 
to the surface of the deposit, to date the length of the period of accumulation. No charcoal was available above a depth of $700 \mathrm{~mm}$ and samples below $2230 \mathrm{~mm}$ were contaminated with disturbed material. The charcoal samples were removed from the foil, weighed on an electronic scale, placed in individual polythene bags, and designated a sample number to be sent to Waikato University Radiocarbon Dating Laboratory for dating (liquid scintillation counting).

Another of Roe's charcoal samples was added to resolve an inconsistency within the first group of dates. The small size of the charcoal sample meant that this had to be dated using accelerated mass spectrometry (AMS). Results are Conventional Age or Percent Modern Carbon (pMC), following Stuiver and Polach (1977). All material dated from Caladenia Cave was calibrated with OxCal, using the SHCal13 Southern Hemisphere calibration curve (Bronk Ramsey 2009; Bronk Ramsey and Lee 2013; Hogg et al. 2013).

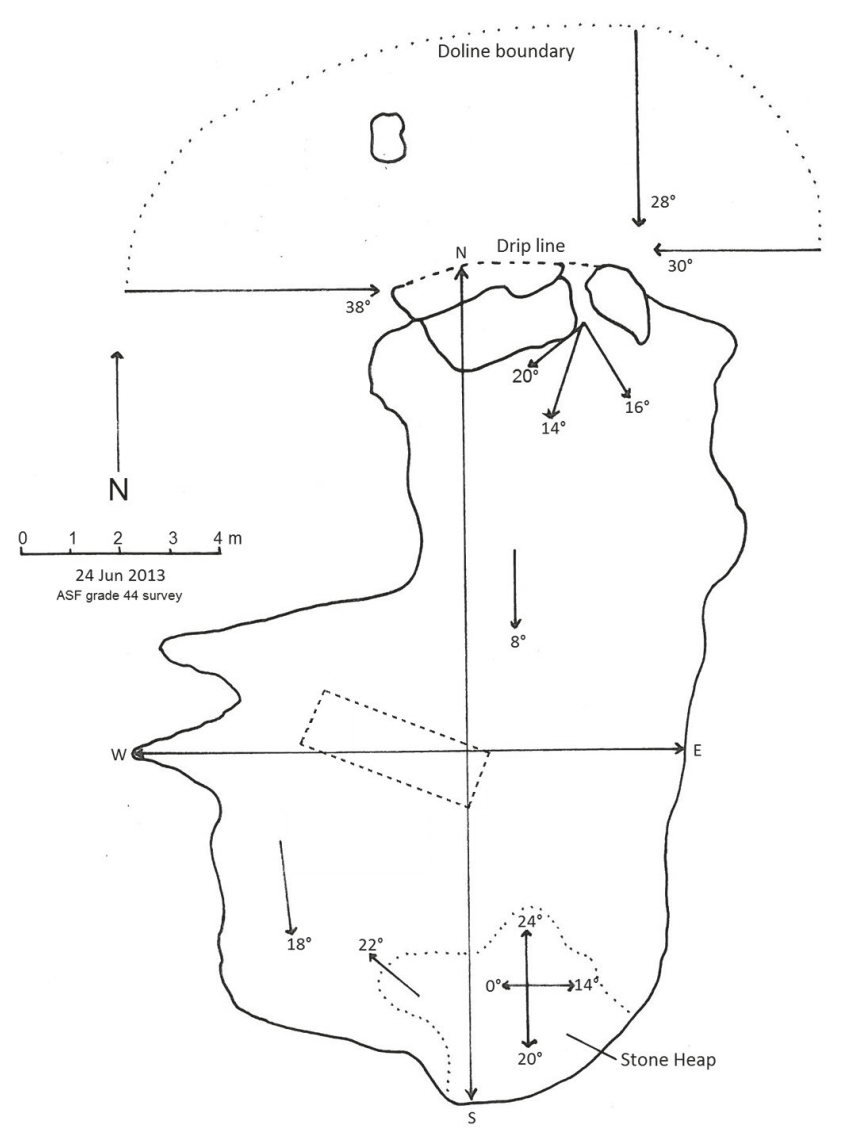

FIGURE 2 Plan view of Caladenia Cave. Angles refer to the direction and slope of the floor. Dashed rectangle indicates the approximate position of Roe's trench.

\section{IDENTIFICATION OF MAMMALS}

Species nomenclature follows Van Dyck and Strahan (2008) except for the Macropodidae and Rodentia for which taxonomy follows Prideaux and Warburton (2010) and Aplin (2006), respectively. Mammal remains were identified to the lowest taxonomic level possible using museum specimens and published descriptions for comparison. Attempts were made to distinguish between species of Sminthopsis using characteristics reported by Archer (1981) and Kitchener et al. (1984). Rodents were identified according to the characteristics reported in Appendix III of Baynes (1979) and his other unpublished notes.

Cranio-dental elements of all mammals were identified. Post-cranial bones (calcanei, humeri, ulnae, femora, scapulae and pelvic elements) of larger mammals (>250 g) were also identified, using the Western Australian Museum fossil reference collection.

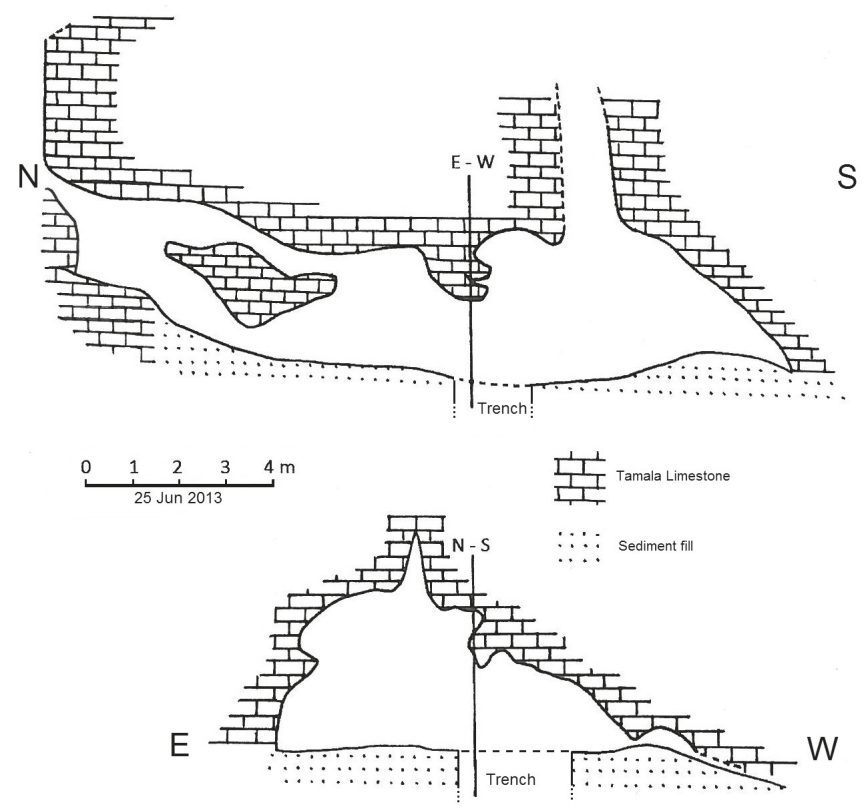

FIGURE 3 Longitudinal and transverse sections of Caladenia Cave. The north-south longitudinal section shows the entrance and edge of the doline on the left. The 'island' of limestone between the roof and floor of the cave is a collapsed part of roof and wall protruding into the section. The entrance slope is supported by large limestone boulders with unknown depths below the surface. The sections show the probable location of the trench inferred from Roe (1971). The protruding section of the ceiling visible in both diagrams is not speleothem development but where part of the ceiling has collapsed leaving an overhang. 
TABLE 1 Designated data Groups used in statistical analyses, selected on the sieve size used and the sediment type recorded during excavation. In Groups A-C all spits were originally measured in inches before metric conversion. Surface was $270 \mathrm{~mm}$ below the datum. Depth measurements which overlap are due to stratigraphic dip and locations in the three named pit sections ('Stone heap end', test pit and 'Wall end'). The lime-flecked units are from the slumped stratigraphy, some of which was 'disturbed' and so measurements do not reflect the entire slump. The $3 \mathrm{~mm}$ sieve Groups I-K from 'Stone Heap End' and the test pit cover the depths also recorded in Groups L-R from 'Wall End'. Spits from 2100-2360 mm are disturbed samples and were excluded. 'Mixed-colour' sediments were not marked in Merrilees' section drawings, but were separated from other spits by Roe and so have been placed in a different Group.

\begin{tabular}{|c|c|c|c|c|c|}
\hline Group & Sieve used & Top of unit (mm) & Base of unit (mm) & Stratigraphic unit & NISP \\
\hline A & $3 \mathrm{~mm}$ & 270 & 524 & Banded orange and brown sediments & 728 \\
\hline B & $3 \mathrm{~mm}$ & 524 & 625.6 & Banded orange and brown sediments & 776 \\
\hline $\mathrm{C}$ & $3 \mathrm{~mm}$ & 625.6 & 752.6 & Banded orange and brown sediments & 737 \\
\hline $\mathrm{D}$ & $3 \mathrm{~mm}$ & 755 & 1050 & Brown sediment (1) & 672 \\
\hline $\mathrm{E}$ & $3 \mathrm{~mm}$ & 1045 & 1100 & Dark brown sediment & 537 \\
\hline $\mathrm{F}$ & $3 \mathrm{~mm}$ & 1100 & 1200 & Brown sediment (2) & 681 \\
\hline G & $3 \mathrm{~mm}$ & 1180 & 1510 & Medium-grained orange sediment & 1047 \\
\hline $\mathrm{H}$ & $3 \mathrm{~mm}$ & 1290 & 1340 & Light brown bands & 61 \\
\hline I & $3 \mathrm{~mm}$ & 1390 & 1560 & Lime-flecked sediment & 180 \\
\hline $\mathrm{J}$ & $3 \mathrm{~mm}$ & 1540 & 1980 & Mixed colour sediment & 227 \\
\hline K & $3 \mathrm{~mm}$ & 1635 & 2420 & Brown sediment (3) & 79 \\
\hline $\mathrm{L}$ & $1 \mathrm{~mm}$ & 1480 & 1600 & Lime-flecked sediment & 773 \\
\hline M & $1 \mathrm{~mm}$ & 1600 & 1660 & Brown sediment (3) & 680 \\
\hline $\mathrm{N}$ & $1 \mathrm{~mm}$ & 1660 & 1720 & Brown sediment (3) & 717 \\
\hline $\mathrm{O}$ & $1 \mathrm{~mm}$ & 1720 & 1840 & Brown sediment (3) & 767 \\
\hline $\mathrm{P}$ & $1 \mathrm{~mm}$ & 1840 & 1960 & Brown sediment (3) & 730 \\
\hline Q & $1 \mathrm{~mm}$ & 1960 & 2100 & Brown sediment (3) & 644 \\
\hline $\mathrm{R}$ & $1 \mathrm{~mm}$ & 2360 & 2500 & Brown sediment (3) & 413 \\
\hline
\end{tabular}

TABLE 2 Radiocarbon dates generated by Waikato University Radiocarbon Dating Laboratory from charcoal samples collected during the 1970s Caladenia Cave excavations. The sample codes correspond to Caladenia Cave (CC) and the average depth of the source spit in centimetres (as originally recorded).

\begin{tabular}{lrrrrr} 
Sample code & Depth $(\mathrm{mm})$ & Group & Waikato code & Radiocarbon age (BP) & Calibrated age (cal. BP) \\
\hline CC100 & 1000 & D & WK37157 & $2803 \pm 68$ & $3037-2750$ \\
CC108 & 1080 & E & WK37158 & $2986 \pm 58$ & $3254-2925$ \\
CC137 & 1370 & G & WK37159 & $3544 \pm 43$ & $3895-3641$ \\
CC154 & 1540 & J & WK37160 & $3812 \pm 45$ & $4296-3979$ \\
CC160 & 1600 & J & WK37161 & $4256 \pm 56$ & $4868-4569$ \\
CC223 & 2230 & K & WK38730 & $1346 \pm 20$ & $1280-1180$ \\
CC231 & 2310 & K & WK37162 & $1556 \pm 34$ & $1489-1316$ \\
\hline
\end{tabular}




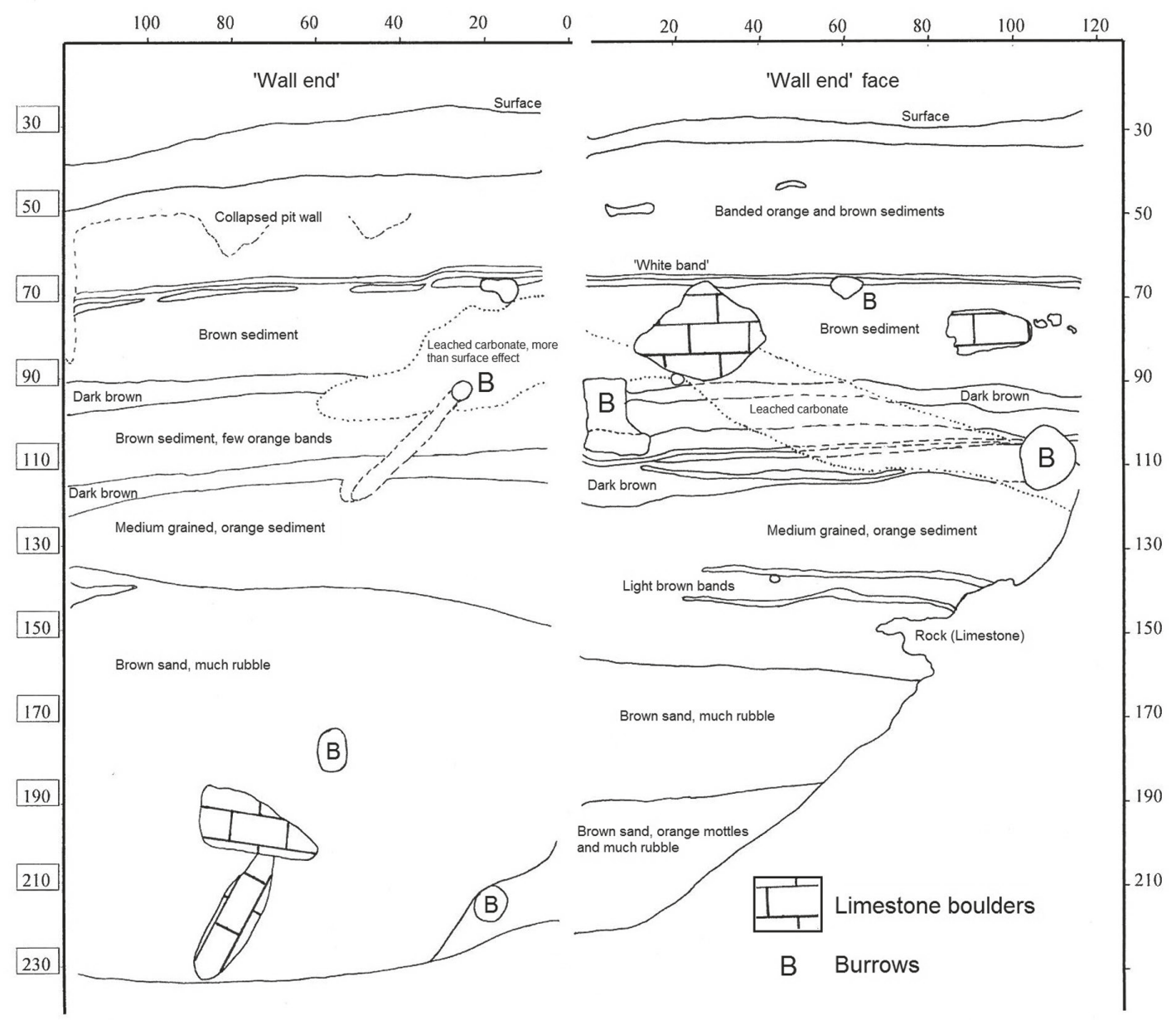

FIGURE 4 Section drawings of 'Wall end' and 'Wall end face', perpendicular faces of the trench. The 0 horizontal point denotes the NW corner of the trench and the datum from which section lines were measured. Burrows in the stratigraphy were either in-filled or contained small frogs. All material from the burrows was labelled disturbed (Roe 1971). All sections were originally sketched by D. Merrilees and redrawn and digitised for this investigation. Illustrations of the other sections are provided in Appendix 2.

\section{PALAEOECOLOGY}

Number of Identified Specimens (NISP) was chosen over the Minimum Number of Individuals as the preferred quantitative unit because it is a more robust measure of taxon abundance (Lyman 2008). NISP was calculated by counting all identified specimens (e.g. left and right dentaries and maxillae, and post-cranial material where identified, see Table 3). However, when edentulous jaws were present, isolated teeth were only counted after teeth corresponding to empty alveoli had been subtracted. Data were combined into Groups designated A-R (see Table 1 for details) based on their stratigraphic position, the sieve size used and to ensure sample sizes were robust enough for statistical analyses. Rarefaction curves were generated for each Group (A-R) using PAST (Hammer et al. 2001), to assess the likelihood that additional specimens would yield additional species (Gotelli and Colwell 2001; Hammer et al. 2001; Lyman and Ames 2007; Hammer and Harper 2008). Correspondence analysis was used to visualise patterns of species abundances in the assemblage.

Body mass statistics were sourced from Van Dyck and Strahan (2008) and the averages were calculated to separate the species into weight classes by $50 \mathrm{~g}$ steps. Relative abundance (Ri\%) was calculated (NISPspecies/ NISPtotal $x$ 100) to elucidate quantitative differences between Groups. Changes in species diversity between Groups were assessed using the Simpson index of diversity $\left(1-\lambda=1-\Sigma p_{\mathrm{i}}^{2}\right)$, which was calculated for both the full fauna and the fauna that remained after the $<50 \mathrm{~g}$ species were removed, for comparison. Species $<50 \mathrm{~g}$ were subtracted from all Groups as many were differentially recovered by the $1 \mathrm{~mm}$ sieve. Each analysis was conducted in PAST and graphed in Excel. Species habitat guilds were generated from references shown in Table A1, Appendix 1. 


\begin{tabular}{|c|c|c|c|c|c|c|c|c|c|c|c|c|c|c|c|c|c|}
\hline exet fo $0 \mathrm{~N}$ & 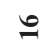 & 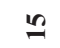 & 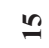 & 2 & 르 & 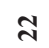 & d & $\Xi$ & $=$ & $\ddot{\sim}$ & $\stackrel{0}{ }$ & $\bar{\sim}$ & $\ddot{\sim}$ & $\tilde{N}$ & $\hat{\sim}$ & $\stackrel{\infty}{\sim}$ & $\underset{\sim}{\Delta}$ \\
\hline dSIN ןetoL & & $\stackrel{2}{*}$ & $\hat{n}$ & ลิ & & $\bar{g}$ & 于 & & 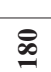 & 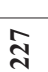 & I & $\stackrel{m}{R}$ & $\mathscr{\not}$ & $\frac{1}{2}$ & & లి & $\underset{G}{ \pm}$ \\
\hline
\end{tabular}

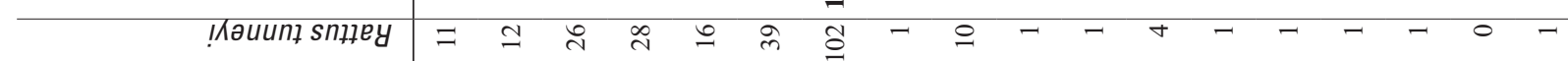

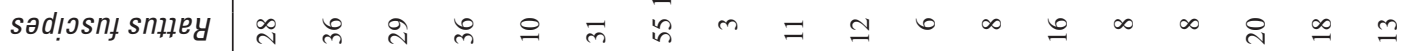

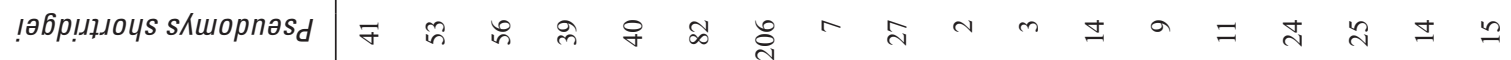

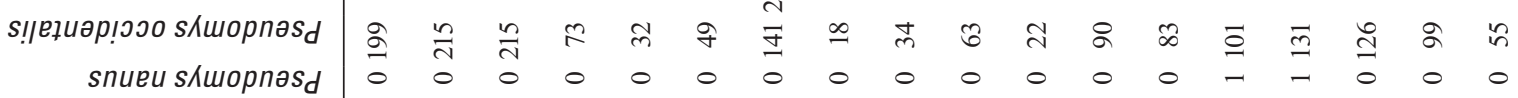

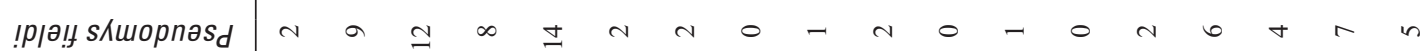

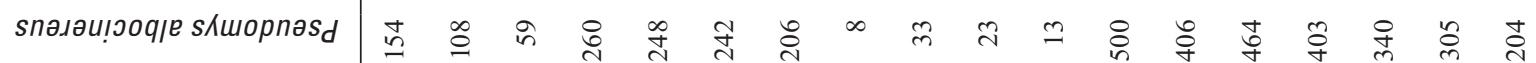

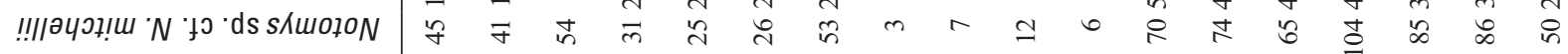

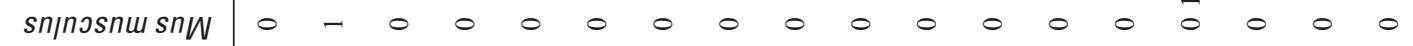
ләльебокицл кАшолин !p ппо6 sп!!цdотоКN !Кодңоәб

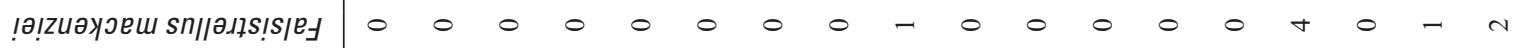

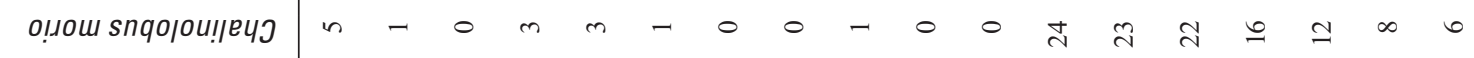

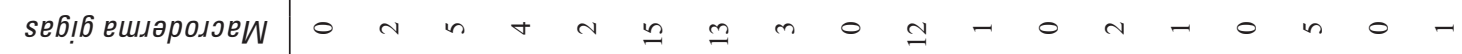

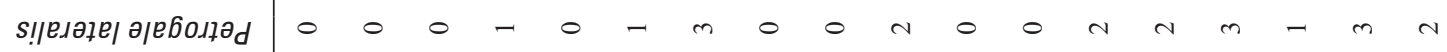

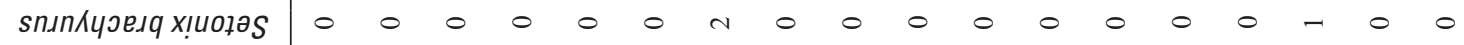
eши! sndoләеW + +

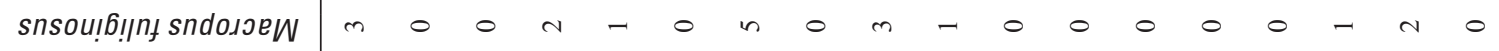

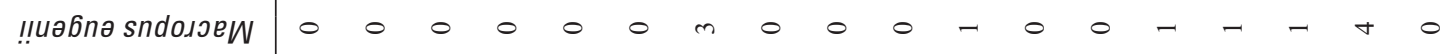

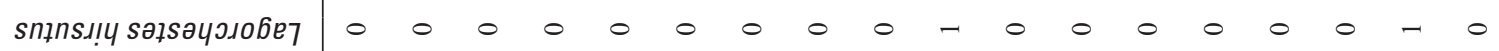

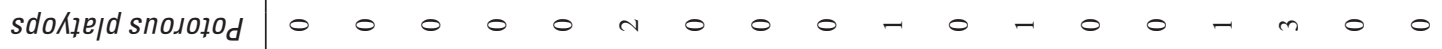

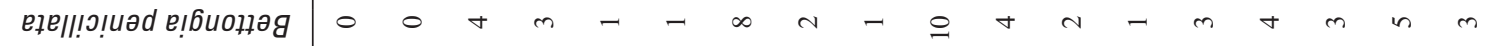

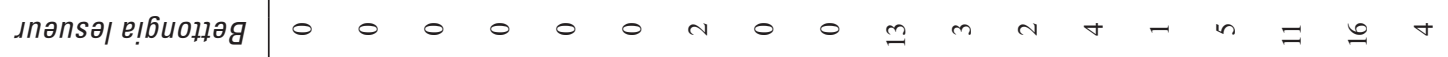

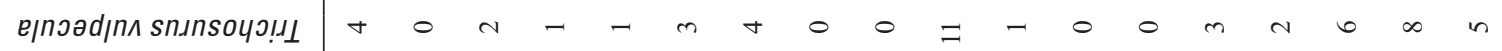

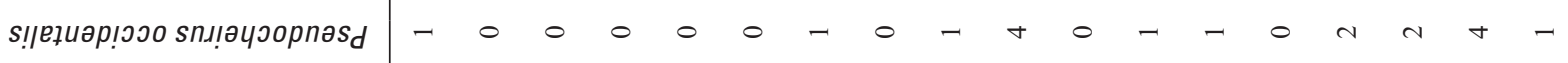

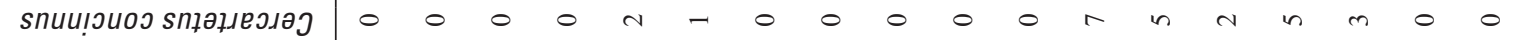

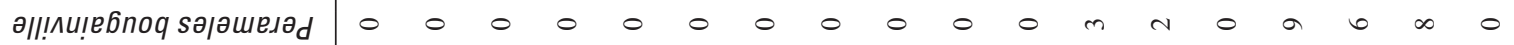

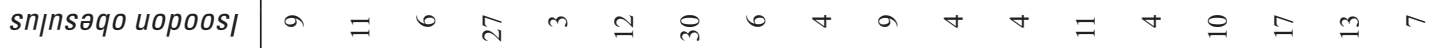

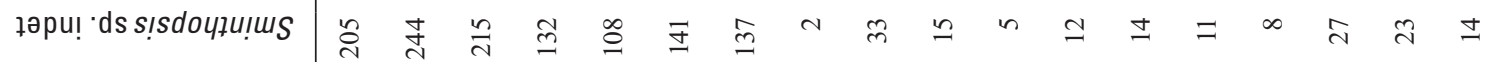

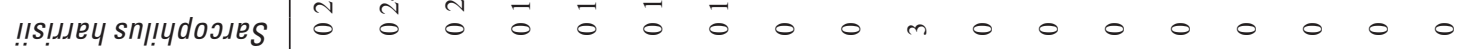

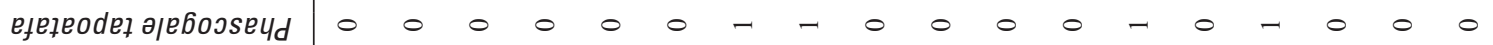

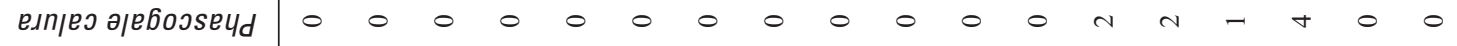

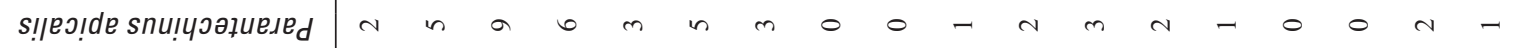

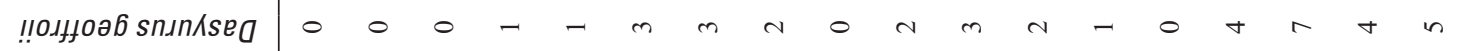

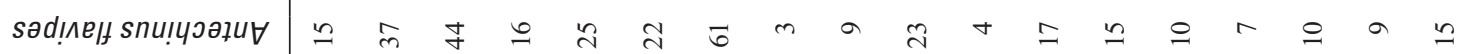

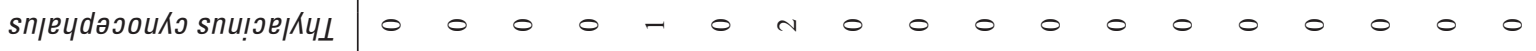
dnoגg

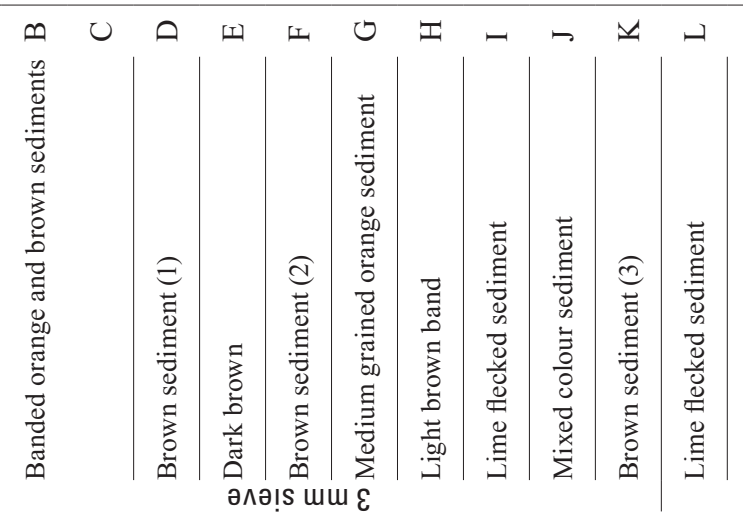

z 0 a 0 品 


\section{RESULTS}

\section{SEDIMENTOLOGY AND STRATIGRAPHY}

The sedimentary sequence in Caladenia Cave is well stratified. No evidence of reworking of the sediments was observed, except where small burrows occurred (Figure 4). Unfortunately, many of the sediment samples collected by Roe were still damp when placed in vials, causing their paper labels to degrade to the point of illegibility, preventing sedimentological analyses.

\section{CHRONOLOGY}

Radiocarbon dates from the sedimentary sequence indicate that the majority of the deposit was undisturbed. Dates CC223 and CC231 are, however, out of sequence (Table 2; Figure 5), probably because of disturbance of sediment by rain washing into the open excavation after a storm (Roe 1974), which would have redeposited much younger material into the trench. All other dates are older and in stratigraphic order, with a high $\mathrm{R}^{2}$ coefficient once the disturbed dates are excluded (Figure 5).

\section{TAPHONOMY}

A majority of the small mammal $(<250$ g mean adult body weight) material recovered from the excavation was intact with very little, to no digestive erosion (Figure 6) or breakage on crania or long bones (Figure 7). This condition is typical of owl accumulation (Andrews 1990).

Mammalian predators and scavengers, Sarcophilus harrisii, Thylacinus cynocephalus and Homo sapiens, contributed to the Caladenia Cave assemblage. Evidence of S. harrisii includes coprolites and shards of bones of larger, indeterminate marsupials, still with a faecal coating, in Group J. Turtle shell and burnt bones, possible evidence of humans, were found in Group K. All specimens of species $>250 \mathrm{~g}$ are incomplete, with saw-tooth breakage patterns and higher levels of surface digestive erosion, and many remains of animals larger than $1 \mathrm{~kg}$ showed evidence of human use (Monks et al. 2014) (Figure 6). The Shapiro-Wilk tests returned significantly low probabilities that both size classes were not normally distributed (see Appendix 3, Tables A3.1 and A3.3). Paired $t$-tests were then conducted, which highlighted that the two size classes are significantly different from one another taphonomically by both percent completeness and evidence of digestive erosion $(\mathrm{p}<0.05$, see Appendix 3, Tables A3.2 and A3.4).

Species $<250 \mathrm{~g}$ are generally represented by $>90 \%$ complete specimens. While much more variable, remains of species $>250 \mathrm{~g}$ often consisted of bone shards, or broken ends of long bones. Bone completeness of species $<250 \mathrm{~g}$ generally decreased with depth in the deposit (Figure 7). This was attributed to the weight of the cave fill, trampling and a weakening of the bone

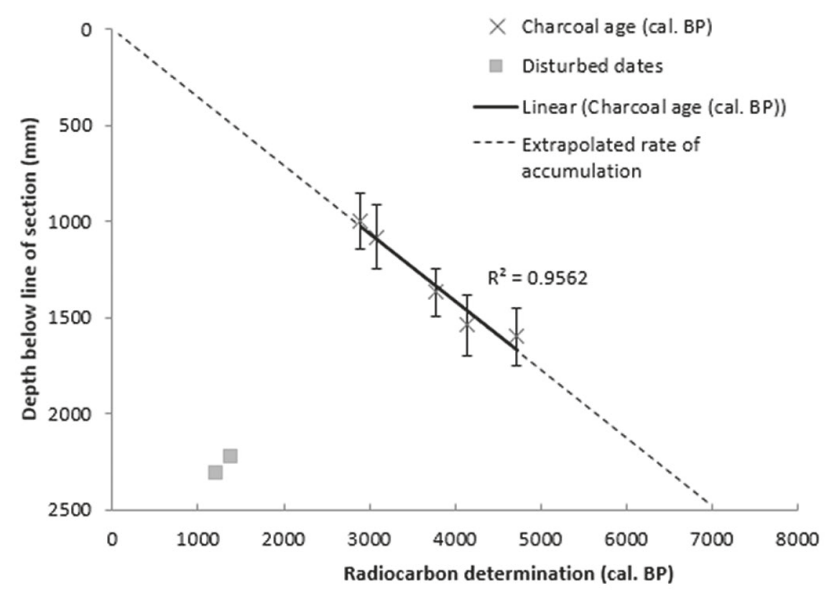

FIGURE 5 Depth-age plot for the deposit in Caladenia Cave. $R^{2}$ value does not include the two disturbed dates represented by grey squares.

\section{Surface digestion damage (\%)}

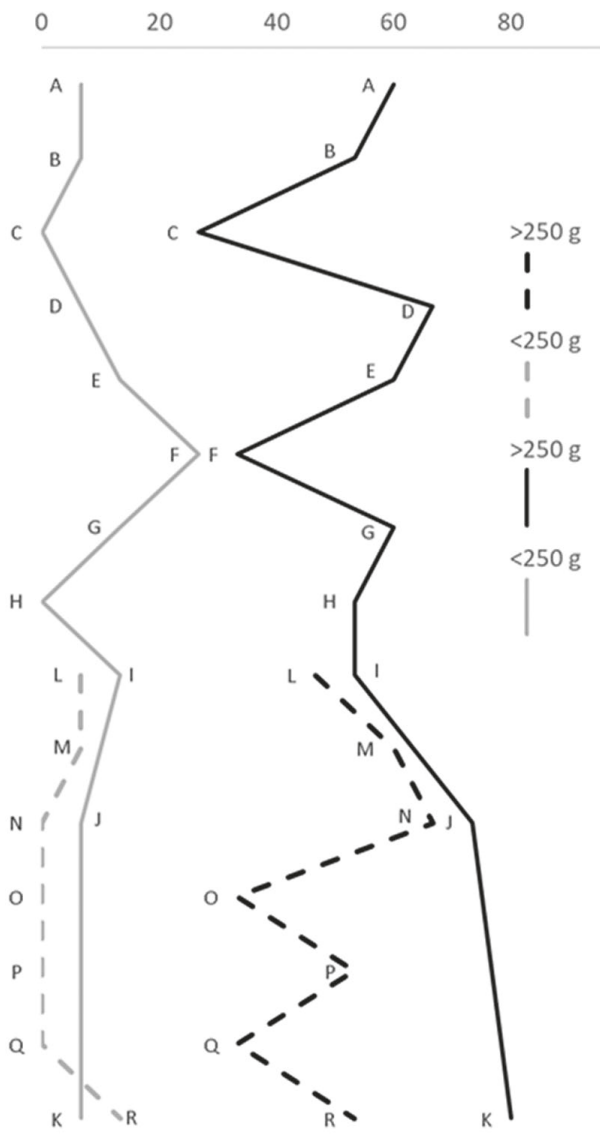

FIGURE 6 The proportion of damage caused by digestion to remains of species $<250 \mathrm{~g}$ and $>250 \mathrm{~g}$. Damage was recorded as percentage of the bone surface showing digestive erosion or bite damage. Solid lines represent the Groups sieved with a $3 \mathrm{~mm}$ mesh aperture, dashed lines with a $1 \mathrm{~mm}$ aperture. 
with age. The specimens recovered from species $>250$ $\mathrm{g}$ appear to have been damaged more by mammalian accumulators such as $S$. harrisii, T. cynocephalus and humans before their deposition.

Six burrows were observed in photographs and sketches of the excavation sections. Notable dark staining of all other specimens from the same depth as a single unstained, pale Mus musculus specimen is consistent with it having been recovered from a small burrow in the deposit (see Table 3). The mouse may have entered the burrow as a living animal, or its remains could have been reworked from the surface by whatever

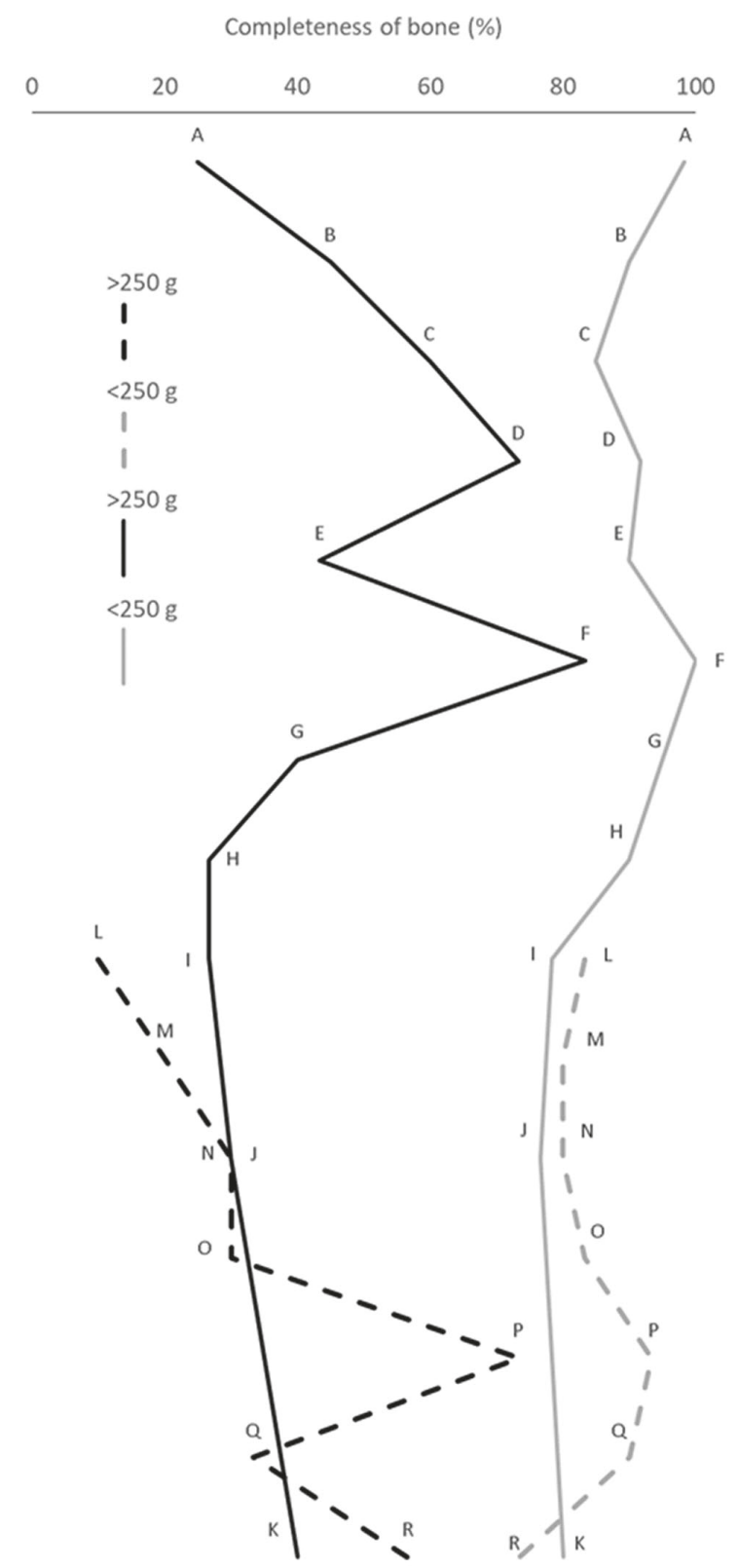

FIGURE 7 Bone breakage shown by remains of species $<250 \mathrm{~g}$ and $>250 \mathrm{~g}$. Solid lines represent the Groups sieved with a $3 \mathrm{~mm}$ mesh aperture, dashed lines with a $1 \mathrm{~mm}$ aperture. made the burrow. Either could explain its depth in the deposit in relation to its recent $(<200$ years) invasion of south-western Australia.

Cranio-dental preservation changed through the deposit, from specimens such as intact skulls and splanchnocrania in the upper $1000 \mathrm{~mm}$ to mainly small fragments of maxillae and dentaries recovered by the 1 $\mathrm{mm}$ sieve in Groups $\mathrm{L}-\mathrm{M}$ and below. In material from the small sieve mesh aperture $(\mathrm{L}-\mathrm{R})$, the ratio of isolated rodent M1s to teeth-bearing bones changed, with most of the NISP counts constituted by molars alone. The mid-range Groups $\mathrm{H}-\mathrm{K}$ (Figure 8) of the deposit contain higher relative abundances of remains of larger species $(>250 \mathrm{~g})$, resulting from natural deaths, scavengers or human accumulation.

The reduction in sieve size by the excavation team, evident in the sharp change in the relative abundance of $<50 \mathrm{~g}$ species between Groups K and L (Figure 8), caused the differential recovery of smaller species.

\section{FAUNA}

A total of 12,407 specimens was identified from the Roe excavation in Caladenia Cave. These have been accessioned into the vertebrate palaeontological collection of the Western Australian Museum under catalogue numbers 13.11.1-13.11.999 and 13.12.113.12.617. In most cases only a single catalogue number was allocated to each species from each spit, irrespective of the number of specimens. Only 10,449 specimens were used for statistical analyses due to disturbance of some of the stratigraphy and excavation problems. The biggest change from species presence to absence occurs at approximately $1600 \mathrm{~mm}$ (Group J), where the marsupials Phascogale calura, Perameles bougainville and Lagorchestes hirsutus and the placental Falsistrellus mackenziei disappear. All of these species were recorded on the basis of jaws or jaw fragments large enough to be retained on a 3 $\mathrm{mm}$ sieve, and had their remains been present in the upper part of the deposit, where bone preservation was relatively good, they would have been recovered. The Falsistrellus mackenziei specimens have extended the known Holocene northern range limit of the species, which was previously Jandakot at $32^{\circ} 15^{\prime} \mathrm{S}, 115^{\circ} 50^{\prime} \mathrm{E}$ (Hosken and O'Shea 1995).

No easily distinguished species of Sminthopsis such as Sminthopsis crassicaudata was identified within the assemblage; other Sminthopsis species could not be separated from one another using the descriptions in Archer (1981) or Kitchener et al. (1984).

Sarcophilus harrisii was represented by jaw fragments, isolated teeth and ascribed coprolites. The coprolite specimens, containing small bone fragments, indicate that Sarcophilus contributed to the accumulation of vertebrate remains in the cave. 


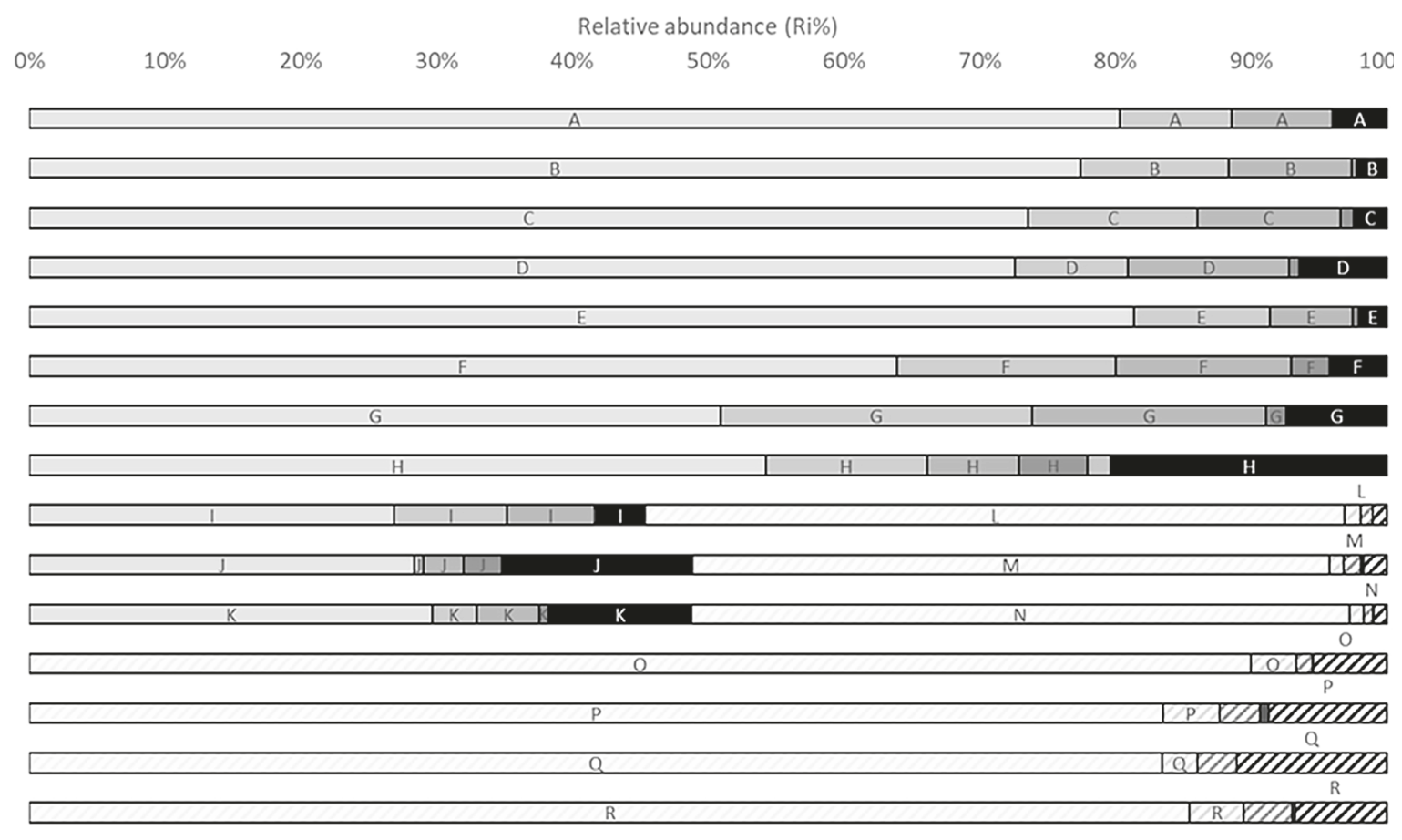

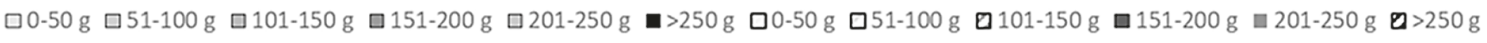

FIGURE 8 The relative abundance of the diagnostic remains recovered from each data Group in Caladenia Cave within allocated average body mass classes.

Evidence of human use of the cave includes hearths described and sketched in Roe's notebooks after a trench wall collapsed (Roe 1974, pp. 39-42). Freshwater mussel shells, turtle shell and fish bones were recovered as well as burnt mammal bone in the lower levels of the deposit (Monks et al. 2014). A fragment of human jaw bone was mentioned in Roe's notebooks (Roe 1971), but cannot be found in the Western Australian Museum collections. Artefacts were also found during the excavation, and catalogued into the Museum archaeological collection (B3086-90, B1979, B1981-82 and A22107-09) providing additional evidence that humans occasionally inhabited the cave.

Three specimens of Thylacinus cynocephalus were recovered from the excavation, each at different depths. The chronologically youngest specimen, a right metatarsal III of Thylacinus cynocephalus (WA Museum vertebrate palaeontological collection catalogue number 13.11.364) has an associated charcoal age of 3254-2925 cal. BP. All Thylacinus specimens were originally identified by Merrilees and confirmed by Thorn with Museum comparative material.

\section{PALAEOECOLOGY}

Rarefaction analysis of the NISP data from each Group (see Figures A-R in Appendix 4), indicated that the smallest Group samples, D, E and I, were all still within one standard deviation of the largest samples' rarefaction curves, and all samples tend towards an asymptote. Group I remained the only sample to not plateau. Therefore, sample sizes and species richness were sufficient for further statistical tests (Gotelli and Colwell 2001; Hammer and Harper 2008).

Correspondence analysis clearly shows a cluster of Groups screened with the $1 \mathrm{~mm}$ aperture sieve (circled in Figure 9). The smaller species, such as the microbats, Pseudomys albocinereus, and Phascogale calura are associated with the $1 \mathrm{~mm}$ sieve aperture Groups, while

TABLE 4 Relative abundances of species grouped according to body mass $(\mathrm{g})$ in the $3 \mathrm{~mm}$ and $1 \mathrm{~mm}$ sieve mesh aperture samples. Body mass data could not be located for some species, therefore Ri\% figures do not total 100 .

\begin{tabular}{lrc} 
Mass $(\mathrm{g})$ & $3 \mathrm{~mm}(\mathrm{Ri} \%)$ & $1 \mathrm{~mm}(\mathrm{Ri} \%)$ \\
\hline $0-50$ & 53.90047 & 86.89071 \\
$51-100$ & 9.43340 & 2.80774 \\
$101-150$ & 8.31425 & 2.22037 \\
$151-200$ & 1.52893 & 0.19437 \\
$201-250$ & 0.15771 & 0.03963 \\
$>250$ & 8.75636 & 5.44026 \\
\hline
\end{tabular}




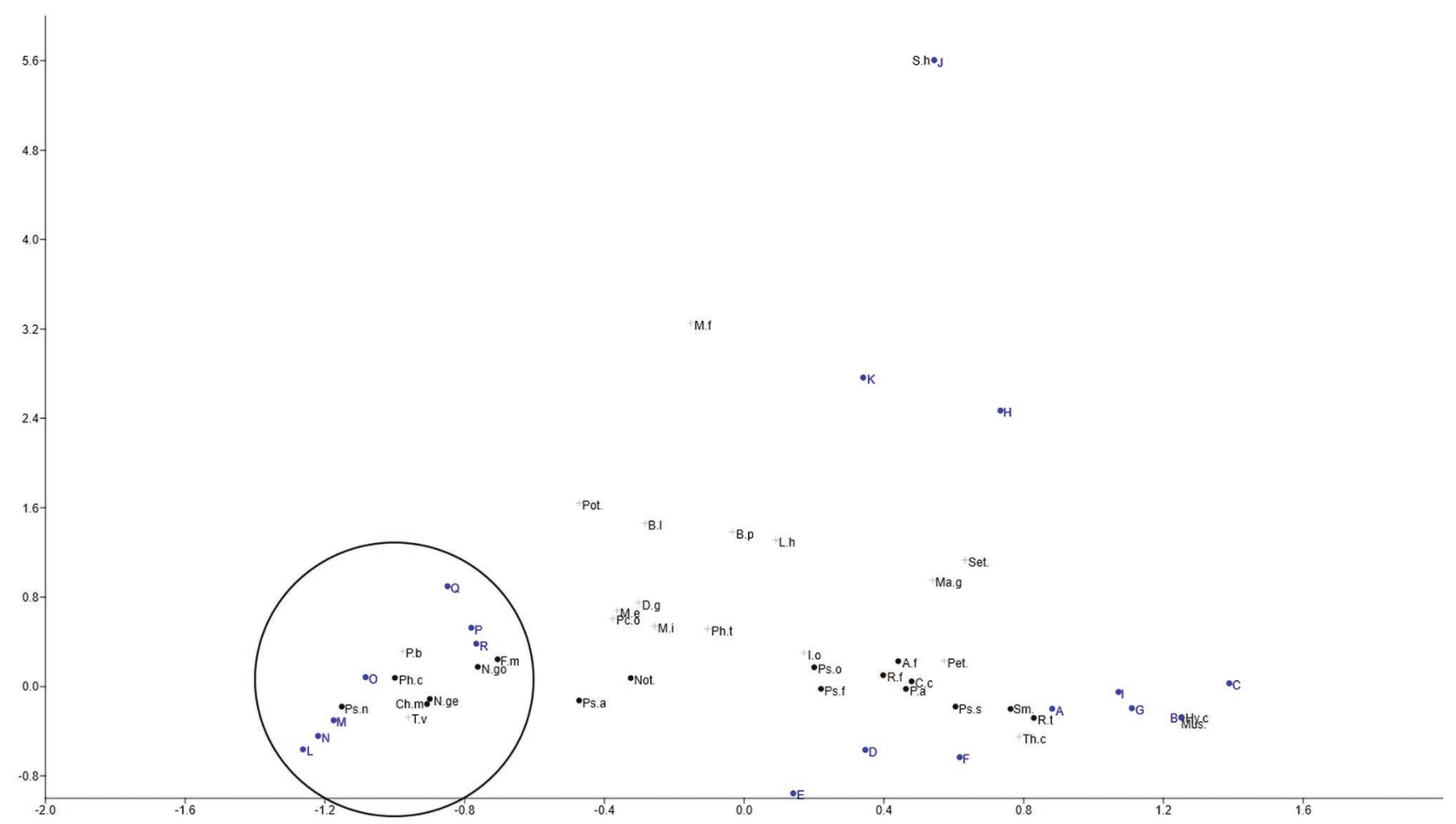

FIGURE 9 Scatter plot of the first two axes of correspondence analysis of the raw Group data from Caladenia Cave. Groups A-K are from the $3 \mathrm{~mm}$ sieve and Groups L-R from the $1 \mathrm{~mm}$. Species $>250 \mathrm{~g}$ are designated with a grey ' + '. Clustered Groups correlating with the $1 \mathrm{~mm}$ sieve are circled, note that this is not a 95\% confidence ellipse. A.f = Antechinus flavipes, D.g = Dasyurus geoffroii, P.a = Parantechinus apicalis, Ph.c = Phascogale calura, Ph.t $=$ Phascogale tapoatafa, $\mathrm{S} . \mathrm{h}=$ Sarcophilus harrisii, $\mathrm{Sm} .=$ Sminthopsis sp. indet, I.o =Isoodon obesulus, P.b = Perameles bougainville, T.v = Trichosurus vulpecula, B.I = Bettongia lesueur, B.p $=$ Bettongia penicillata, Pot. = Potorous platyops, M.e = Macropus eugenii, M.f = Macropus fuliginosus, M.i $=$ Macropus irma, Pet. $=$ Petrogale lateralis, Set. $=$ Setonix brachyurus, C.c $=$ Cercartetus concinnus, Pc.o = Pseudocheirus occidentalis, Ma.g = Macroderma gigas, Ch.m = Chalinolobus morio, F.m = Falsistrellus mackenziei, N.ge = Nyctophilus geoffroyi, N.go = Nyctophilus gouldi, Hy.c = Hydromys chrysogaster, Mus. $=$ Mus musculus, Not. = Notomys sp. cf. N. mitchellii, Ps.a $=$ Pseudomys albocinereus, Ps.f $=$ Pseudomys fieldi, Ps.n = Pseudomys nanus, Ps.o = Pseudomys occidentalis, Ps.s = Pseudomys shortridgei, R.f = Rattus fuscipes, R.t = Rattus tunneyi.

most of the larger species do not obviously cluster with any Group. Notably, Sarcophilus sits directly under Group J, and Hydromys and Mus musculus under Group $\mathrm{B}$, as these species appear only in these Groups. The remaining rodents and dasyurids are generally spread out across the plot, not clustering with any particular Group, possibly due to variation in preservation causing them to be variably retained by both sieves throughout the deposit.

When the different faunal size classes were further examined (Table 4) the relative abundances of the smallest species $(<50 \mathrm{~g})$ were significantly higher in Groups where a $1 \mathrm{~mm}$ sieve was used $(\mathrm{p}<0.05)$.

The Simpson index of diversity was found to be fairly consistent through the upper levels of the deposit until the change in sieve size between Groups $\mathrm{K}$ and $\mathrm{L}$ (Figure 10). The Groups I-K record a Simpson index of 0.8 or higher, while the same depths sieved with the $1 \mathrm{~mm}$ aperture, represented by Groups L-N, drop to
0.5. Despite an increase in sample size the diversity index does not revert again until Group R. This may be explained by an increase in the recovery of smaller specimens resulting from a finer sieve mesh aperture. Relative abundance of $0-50 \mathrm{~g}$ species increased from $53.9 \%$ to $86.9 \%$ of the recovered material (Table 4 ), but while the sample sizes increased, the number of taxa did not, generating a false impression of a drop in diversity.

Species were grouped into habitat guilds based on current knowledge of ecological preferences, after Adams et al. (2016). Relative abundances of habitat guilds show major fluctuations below Group G (Figure 11). This is most likely to have been caused by differential recovery of the material in those spits that were only sampled by the $3 \mathrm{~mm}$ sieve, whereas the same depths covered in Groups L-R, sampled with the $1 \mathrm{~mm}$ sieve, from the other 'End' of the trench, show much less fluctuation. 


\section{DISCUSSION}

The investigation into the fossil vertebrate fauna of Caladenia Cave unearthed a total of 38 native mammal species, consisting of 14 placentals and at least 22 marsupials (Sminthopsis and Dasycercus were only identified to genus and could each represent two or more species). Current faunal records report only 11 extant native species, the top layer of the deposit alone records 16 , and historical records place 28 species in the same area (Wilson et al. 2012). These figures highlight the value of Holocene fossil deposits as records of the original mammalian species richness of the Swan Coastal Plain. The drop in species richness on the northern Swan Coastal Plain can only be attributed to

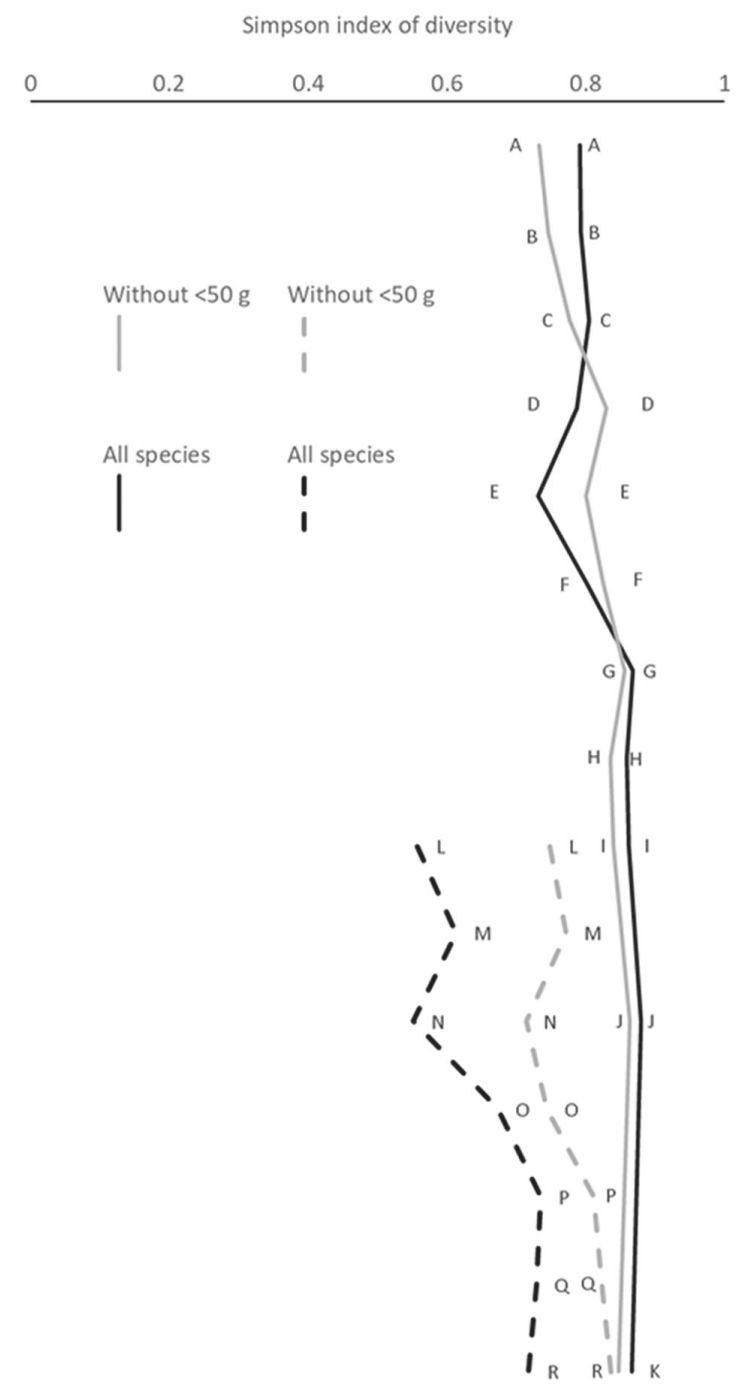

FIGURE 10 Simpson index of diversity of each Group in Caladenia Cave. When all species with a body mass of less than $50 \mathrm{~g}$ were removed from the entire dataset, diversity across the deposit appears more even. Solid lines represent the Groups sieved with a $3 \mathrm{~mm}$ mesh aperture, dashed lines with a $1 \mathrm{~mm}$ aperture. the impacts of European settlement, as other factors, the changes in rainfall or the arrival of the dingo in the area, have not produced the same dramatic effect anywhere in this long-term data set.

\section{TAPHONOMY}

The body mass range, condition and breakage patterns observed in a majority of the fossil mammal assemblage from Caladenia Cave are characteristic of an owl accumulation (Andrews 1990; Lyman 2012a). Tyto delicatula Gould, 1837, the Australian barn owl, is the species most likely responsible for the accumulation, as a majority of the postcranial material examined shows little or no digestive erosion of the bone surface and most long bones are intact (see Figures 6-7). Tyto delicatula has been recorded on the northern Swan Coastal Plain (Storr et al. 1978; Atlas of Living Australia 2013). The majority of the prey material is composed of rodents and small marsupials, most of which can be swallowed whole by owls (Morton and Martin 1979; Andrews 1990; McDowell and Medlin 2009).

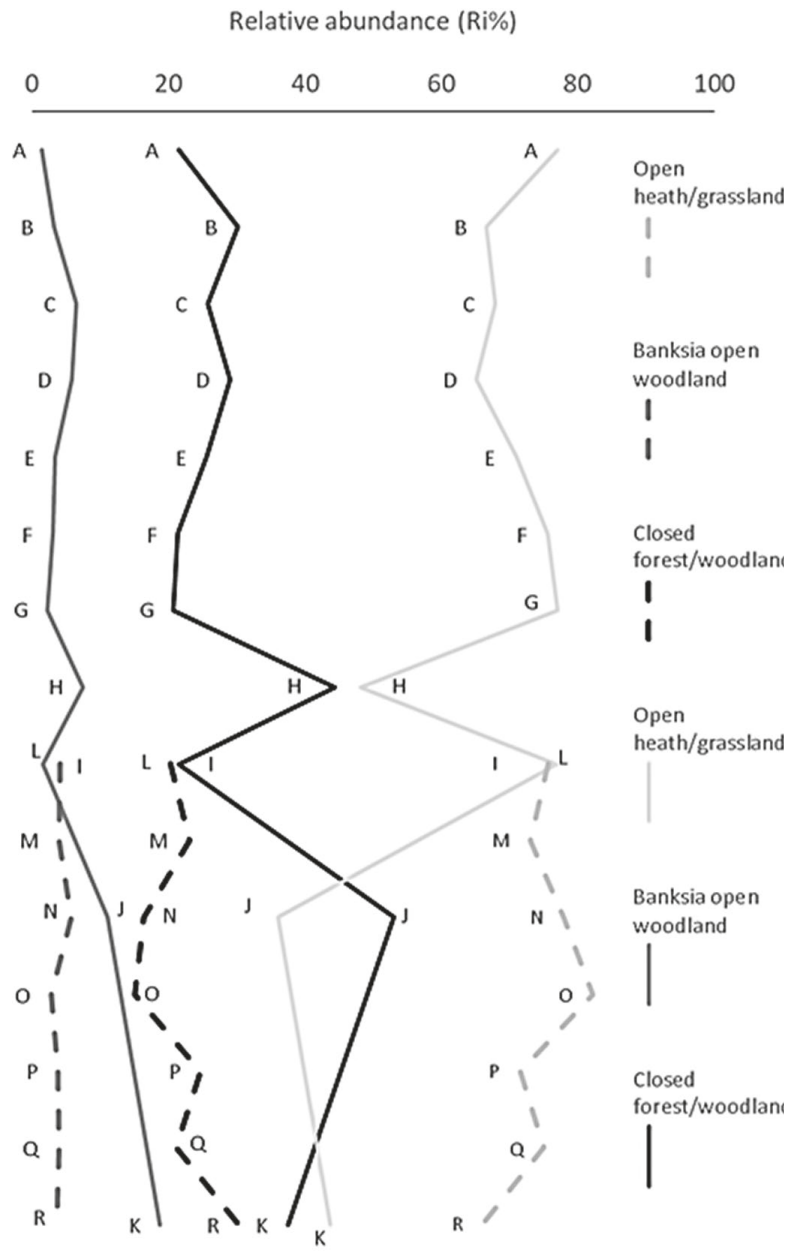

FIGURE 11 Changes in relative abundances of habitat guilds of fossil mammal species $>50 \mathrm{~g}$ in Caladenia Cave. Species were grouped according to information displayed in Appendix 1. 
The use of a sieve of larger mesh aperture for the upper levels of the excavation caused differential recovery of the largest and loss of the smallest mammals, particularly in the deeper layers where the bone was more fragile, creating a bias in the species' relative abundances through time (Lyman 2012b). Where the $3 \mathrm{~mm}$ sieve was used, a lower proportion of the smaller species such as Sminthopsis sp. indet., Cercartetus concinnus, Chalinolobus morio and Pseudomys albocinereus was recovered, as evident in the correspondence analysis (Figure 9). Isolated molars, canines or even entire maxillae from these species with a minimum dimension of $\sim 2 \mathrm{~mm}$, were less likely to be retained than those of larger species (Lyman 2012b). Although Caladenia Cave was excavated in the 1970s, differential recovery is still not uncommon in palaeontological and archaeological investigations and is often not considered in analyses (Baynes personal observation 2016). The results of the Caladenia Cave analyses demonstrate that sieve bias can overwhelm the palaeoecological signal in relative abundance data. Screen mesh aperture is an important factor that should be considered in planning the methodology of an excavation. Preliminary research into the size of the expected specimens, and how they were accumulated is wanted, as well as the use of an appropriate minimum sieve mesh aperture when small faunal material is present in a deposit.

\section{EVIDENCE FOR CLIMATE CHANGE}

Three semi-arid and arid-dwelling species, Phascogale calura (Figure 12), Perameles bougainville and Lagorchestes hirsutus, are present in the deposit below a depth of 1540-1600 mm (Group J, 4868-4569 cal. BP; Table 2), but absent above it. These three species are part of a suite of six which shows the same pattern of change from presence to absence in the mid Holocene levels of the deposit in Hastings Cave, about $120 \mathrm{~km}$ north of Caladenia Cave on the Swan Coastal Plain (Baynes 1979). Moreover, there are no specimens of the three species in the Western Australian Museum vertebrate palaeontological collection from cave floor surface faunas (of late Holocene age) from any of the many caves in the northern Swan Coastal Plain represented in that collection; see, for example, the distribution records for P. calura in Figure 12. This pattern of faunal change suggests that local winter rainfall increased. The other semi-arid and arid proxy species in this group (Perameles bougainville and Lagorchestes hirsutus) also have live-caught records from areas of low winter rainfall (Atlas of Living Australia 2013).

Support for this change was previously found south of Caladenia Cave: invertebrate climate proxies relating to the flow of the Swan River indicating an increase in effective rainfall since 4853-4292 cal. BP (Kendrick 1977; Yassini and Kendrick 1988).

\section{PALAEOECOLOGY}

The change in sieve mesh aperture size generated a more precise representation of the $<50 \mathrm{~g}$ mammals in the lower layers of the Caladenia Cave deposit. This action, taken part way through the excavation, means that the bulk of the youngest material collected has been biased such that smaller mammals are underrepresented. Correspondence analysis was initially applied to the relative abundances of each species recovered from each layer. The resulting plot shows that species and layers grouped in accordance with the size of the sieve used (Figure 9). Consequently, an unbiased interpretation of ecological change over time based on relative abundances was not possible (see also Figure 10 for how diversity, calculated with relative abundances, was impacted by differential recovery). The change in sieve size appears to correlate directly with the change in abundance of the smallest species $(<50 \mathrm{~g})$, which in turn affects the Simpson diversity index for Groups L-R where sample size increases but species richness does not, creating a downward trend in overall diversity in comparison to Groups I-K (3 mm sieved units). Change

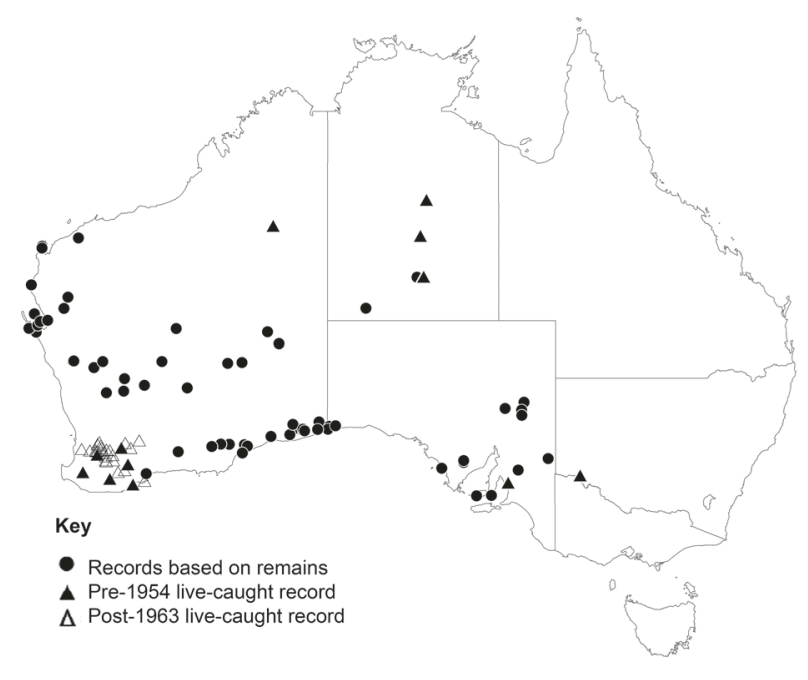

FIGURE 12 The distribution of Phascogale calura. The species was restricted to areas characterised by persistently dry hot summers, with semi-arid to arid climates (Kitchener et al. 1980; Australian Bureau of Meteorology 2013). The gap between mid-latitude and southern records in Western Australia reflects a lack of sites containing mammal remains rather than an absence of original populations, except that, being arboreal, $P$. calura did not occur on the treeless Nullarbor Plain. Data from Thomas (1888), Wakefield (1966), Parker (1973), Baynes and Baird (1992), Baynes and Johnson (1996), Baynes and McDowell (2010), the vertebrate palaeontological and mammal collections of the Western Australian Museum and the mammal collection of the South Australian Museum. 
in the preservation of material seems to also have disrupted any ecological patterns in the data, evident in the 'noise' shown in Figure 11. A trend of mostly open heath/grassland species appears to be disrupted in units $\mathrm{L}-\mathrm{G}$ by an increase in larger species' relative abundance. This is most likely due to the taphonomic features of bone breakage and digestion (Figures 6 and 7) decreasing preservation of the bone, leading to differential recovery in the $3 \mathrm{~mm}$ sieved Groups.

An important finding uncovered by the excavation of Caladenia Cave, not impacted by differential recovery, is the presence of a specimen of Thylacinus cynocephalus with an associated radiocarbon date of 3254-2925 cal. BP. Until now, the youngest mainland Australian specimen of Thylacinus is dated to 3379-3060 cal. BP (McDowell 1997). The timing of the mainland thylacine extinction has been directly associated with the arrival of the dingo at 3904-3445 cal. BP (Milham and Thompson 1976). Fillios et al. (2012) described the impact of dingo immigration on the fauna of mainland Australia as a 'trophic cascade', as it interrupted the thylacine's suppressive effect on herbivores and small predators, indirectly impacting smaller herbivores and vegetation. By contrast, the only significant faunal change discovered in Caladenia Cave pre-dates the arrival of the dingo. Similar results were found in an investigation of Hastings Cave (Baynes 1979), demonstrating a lack of evidence for any 'trophic cascade' occurring on the northern Swan Coastal Plain.

Other than the loss of the dry-land species due to increased rainfall, fine scale local changes in the palaeoecology of the northern Swan Coastal Plain cannot be elucidated. The continued presence of most species throughout the assemblage suggests ecological stability during the Holocene, despite apparent changes in rainfall or the arrival of the dingo. This is in contrast to the effects of European settlement in the area which resulted in local extinction of many mammals such as Parantechinus, Pseudocheirus and five of the seven native rodent species, and a drastic change from all native vegetation to an agricultural mosaic

\section{THE FUTURE}

Because of the limitations imposed on the Caladenia Cave data by differential recovery of mammal remains, further research is needed to elucidate the relationships between the original biotic communities of the Swan Coastal Plain. A re-investigation of the vertebrate assemblage in Wedge's Cave (Lundelius 1960), the ongoing investigation of Yellabiddie Cave (Monks et al. 2016) or another excavation of the East Moore caves, may provide the material required for a palaeoecological comparison with both Hastings and Caladenia Cave. This study shows that excavated sediment must be processed using a $1 \mathrm{~mm}$ or $0.5 \mathrm{~mm}$ sieve mesh aperture for the entire excavation. Unfortunately, future excavation of Caladenia Cave would not be practical as the ideal location and much of the remaining sediment has already been disturbed. However, 30 other caves have been recorded in the 'Lower South West' region that should be explored for fossil remains (Matthews 1985). Evidence collected from other caves further south could also extend the range of interpretation of the Holocene Swan Coastal Plain and provide more information for restoration ecology.

\section{ACKNOWLEDGEMENTS}

Thanks to Mikael Siversson and the Western Australian Museum Department of Earth and Planetary Sciences, for access to both the Caladenia Cave specimens and reference material; Matthew McDowell and Gavin Prideaux for further supervision and their comments on drafts of this paper; Carly Monks, for her archaeological contributions; Cassia Piper, Fletcher Young, Andy Spate and Rob Foulds for field assistance, and the Borwick family for access to the cave on their property. Kaylene Butler and Kenny Travouillon made many constructive comments as referees that greatly improved the paper. Matthew McDowell generated Figure 12 for us. Waikato University Radiocarbon Laboratory performed all of the radiocarbon dating analyses. K.M.T. is grateful to Jamie O'Shea for introducing her to the field of vertebrate zoology and osteology.

\section{REFERENCES}

Adams, S.J., McDowell, M.C. and Prideaux, G.J. (2016). Understanding accumulation bias in the ecological interpretation of archaeological and palaeontological sites on Kangaroo Island, South Australia. Journal of Archaeological Science: Reports 7: 715-729.

Anderson, E.G. (1997). ASF cave survey and map standards. K. Grimes (ed), Australian Speleological Federation. http:// www.caves.org.au/administration/commissions/survey-andmapping-standards. [Accessed on 1 April 2013.]

Andrews, P. (1990). Owls, caves and fossils. The Natural History Museum: London.

Aplin, K.P. (2006). Ten million years of rodent evolution in Australasia: Phylogentic evidence and a speculative historical biogeography. Evolution and biogeography of Australasian vertebrates. Merrick, J.R., Archer, M., Hickey, G.M. and Lee, M.S.Y., eds. Auscipub: Australia: 707-744.

Archer, M. (1981). Results of the Archbold Expeditions No. 104. Systematic revision of the marsupial dasyurid genus Smithopsis Thomas. Bulletin of the American Museum of Natural History 168: 61-223.

Atlas of Living Australia (2013). www.ala.org.au. [Accessed on 2 April 2013.]

Australian Bureau of Meteorology (2013). Australian Climate Influences. www.bom.gov.au//watl/about-weather-andclimate/australian-climate-influences.shtml. [Accessed 20 June 2013.]

Balme, J., Merrilees, D. and Porter, J.K. (1978). Late Quaternary mammal remains, spanning about 30,000 years, from excavations in Devil's Lair, Western Australia. Journal of The Royal Society of Western Australia 61: 33-65.

Barron, O., Silberstein, R., Ali, R., Donohue, R., McFarlane, D. J., Davies, P., Hodgson, G., Smart, N. and Donn, M. (2012). Climate change effects on water-dependent ecosystems in south-western Australia. Journal of Hydrology 434-435: 95-109. 
Bastian, L. (1964). Morphology and development of caves in the Southwest of Western Australia. Helictite 2: 105-119.

Baynes, A. (1979). The analysis of a late Quaternary mammal fauna from Hastings Cave, Jurien. Unpublished PhD Thesis, The University of Western Australia.

Baynes, A. and Baird, R.F. (1992). The original mammal fauna and some information on the original bird fauna of Uluru National Park. The Rangeland Journal 14: 92-106.

Baynes, A. and Johnson, K.A. (1996). The contributions of the Horn Expedition and cave deposits to knowledge of the original mammal fauna of central Australia. In: Morton, S.R. and Mulvaney, D.J., (eds), Exploring central Australia: society, the environment and the 1894 Horn Expedition. Surrey Beatty \& Sons: Chipping Norton, Australia (pp 168-186).

Baynes, A. and McDowell, M.C. (2010). The original mammal fauna of the Pilbara biogeographic region of north-western Australia. Records of the Western Australian Museum. Supplement 78: 285-298.

Baynes, A., Merrilees, D. and Porter, J.K. (1976). Mammal remains from the upper levels of a late Pleistocene deposit in Devil's Lair, Western Australia. Journal of The Royal Society of Western Australia 58: 97-126.

Bronk Ramsey, C. (2009). Bayesian analysis of radiocarbon dates. Radiocarbon 51: 337-360.

Bronk Ramsey, C. and Lee, S. (2013). Recent and planned developments of the program OxCal. Radiocarbon 55: 3-4.

Dortch, J. (2004). Late Quaternary vegetation change and the extinction of Black-flanked Rock-wallaby (Petrogale lateralis) at Tunnel Cave, southwestern Australia. Palaeogeography, Palaeoclimatology, Palaeoecology 211: 185-204.

Fillios, M., Crowther, M.S. and Letnic, M. (2012). The impact of the dingo on the thylacine in Holocene Australia. World Archaeology 44: 118-134.

Gotelli, N.J. and Colwell, R.K. (2001). Quantifying biodiversity: procedures and pitfalls in the measurement and comparison of species richness. Ecology Letters 4: 379-391.

Hammer, Ø. and Harper, D.A.T. (2008). Paleontological data analysis. Wiley: Oxford.

Hammer, Ø., Harper, D.A.T. and Ryans, P.D. (2001). PAST: Paleontological statistics software package for education and data analysis. Paleontologia Electronica 4: 9.

Hogg, A.G., Hua, Q., Blackwell, P.G., Niu, M., Buck, C.E., Guilderson, T.P., Heaton, T.J., Palmer, J.G., Reimer, R.W., Turney, C.S.M. and Zimmerman, S.R.H. (2013). SHCal13 Southern Hemisphere Calibration, 0-50,000 years cal BP. Radiocarbon 55: 1889-1903.

Hosken, D.J. and O'Shea, J.E. (1995). Falsistrellus mackenziei at Jandakot. The Western Australian Naturalist 19: 351.

Kendrick, G.W. (1977). Middle Holocene marine molluscs from near Guildford, Western Australia, and evidence for climate change. Journal of The Royal Society of Western Australia 59: 97-104.

Kitchener, D.J., Chapman, A. and Barron, G. (1978). Mammals of the northern Swan coastal plain. Faunal studies of the northern Swan Coastal Plain: consideration of faunal changes and recommendations. Unpublished report of the Western Australian Museum: Perth: 54-92.

Kitchener, D.J., Chapman, A., Muir, B.G. and Palmer, M. (1980). The conservation value for mammals of reserves in the Western Australian Wheatbelt. Biological Conservation 18: 179-207.

Kitchener, D.J., Stoddart, J. and Henry, J. (1984). A taxonomic revision of the Sminthopsis murina complex (Marsupialia, Dasyuridae) in Australia, including descriptions of four new species. Records of the Western Australian Museum 11: 201-247.
Lundelius, E. Jr (1957). Additions to knowledge of the ranges of Western Australian mammals. The Western Australian Naturalist 5: 173-182.

Lundelius, E.L. Jr (1960). Post Pleistocene faunal succession in Western Australia and its climatic interpretation. International Geological Congress XXI(IV): 142-153.

Lundelius, E.L. Jr (2006). Cave site contributions to vertebrate history. Alcheringa Special Issue 1: 195-210.

Lyman, R.L. (2008). Quantitative Palaeozoology. Cambridge University Press: Cambridge.

Lyman, R.L. (2012a). Rodent-prey content in long-term samples of Barn Owl (Tyto alba) pellets from the northwestern United States reflects local agricultural change. The American Midland Naturalist 167: 150-163.

Lyman, R.L. (2012b). The influence of screen mesh size, and size and shape of rodent teeth on recovery. Journal of Archaeological Science 39: 1854-1861.

Lyman, R.L. and Ames, K.M. (2007). On the use of speciesarea curves to detect the effects of sample size. Journal of Archaeological Science 34: 1985-1990.

Matthews, P.G., ed. (1985). Australian karst index. Australian Speleological Federation Inc: Melbourne.

McDowell, M.C. (1997). Taphonomy and palaeoenvironmental interpretation of a late Holocene deposit from Black's Point Sinkhole, Venus Bay, S.A. Proceedings of the Linnean Society of New South Wales 117: 79-95.

McDowell, M.C., Baynes, A., Medlin, G.C. and Prideaux, G.J. (2012). The impact of European colonization on the lateHolocene non-volant mammals of Yorke Peninsula, South Australia. The Holocene 22: 1441-1450.

McDowell, M.C. and Medlin, G.C. (2009). The effects of drought on prey selection of the barn owl (Tyto alba) in the Strzelecki Regional Reserve, north-eastern South Australia. Australian Mammalogy 31: 47-55.

Merrilees, D. (1967). Fossil bandicoots (Marsupialia, Peramelidae) from Mammoth Cave, Western Australia, and their climatic implications. Journal of The Royal Society of Western Australia 50: 121-128.

Milham, P. and Thompson, P. (1976). Relative antiquity of human occupation and extinct fauna at Madura Cave, southeastern Western Australia. Mankind 10: 175-180.

Monks, C.E., Thorn, K.M., Baynes, A. and Dortch, J. (2014). An archaeological and palaeoecological investigation of Caladenia Cave, northern Swan Coastal Plain, Western Australia. Proceedings of the AAA/ASHA 2014 Joint Conference. Cairns, Australia.

Monks, C., Dortch, J., Jacobsen, G., Baynes, A. (2016). Pleistocene occupation of Yellabidde Cave in the northern Swan Coastal Plain, southwestern Australia. Australian Archaeology 82: 275-279.

Morton, S.R. and Martin, A.A. (1979). Feeding ecology of the barn owl, Tyto alba, in arid southern Australia. Australian Wildlife Research 6: 191-204.

Parker, S. (1973). An annotated checklist of the native land mammals of the Northern Territory. Records of the South Australian Museum 16(11): 1-57.

Prideaux, G.J., Gully, G.A., Couzens, A.M.C., Ayliffe, L.K., Jankowski, N.R., Jacobs, Z., Roberts, R.G., Hellstrom, J.C., Gagan, M.K. and Hatcher, L.M. (2010). Timing and dynamics of Late Pleistocene mammal extinctions in southwestern Australia. Proceedings of the National Academy of Sciences of the United States of America 107: 22157-22162.

Prideaux, G.J. and Warburton, N.M. (2010). An osteology-based appraisal of the phylogeny and evolution of kangaroos and wallabies (Macropodidae: Marsupialia). Zoological Journal of the Linnean Society 159: 954-987. 
Roe, R. (1971). Caladenia Cave notebook No.1 (1970-71). Held in the palaeontological collection of the Western Australian Museum.

Roe, R. (1974). Caladenia Cave notebook No.3 (1972-1974). Held in the palaeontological collection of the Western Australian Museum.

Storr, G.M., Johnstone, R.E. and Harold, G. (1978). Birds of the northern Swan coastal plain, Western Australia. Faunal studies of the northern Swan Coastal Plain: consideration of faunal changes and recommendations. Unpublished report of the Western Australian Museum: Perth: 93-170.

Stuiver, M. and Polach, H.A. (1977). Discussion; reporting of ${ }^{14} \mathrm{C}$ data. Radiocarbon 19: 355-363.

Susac, R.A.J. (2007). A literature review \& report of karst biodiversity, palaeontology \& hydrology in the Northern Agricultural Region, Western Australia. Unpublished report to the Department of Environment and Conservation.

Thomas, O. (1888). Catalogue of the Marsupialia and Monotremata in the collection of the British Museum
(Natural History). British Museum (Natural History): London.

Van Dyck, S. and Strahan, R., (eds) (2008). The mammals of Australia. 3rd edition. Reed New Holland: Sydney.

Wakefield, N.A. (1966). Mammals of the Blandowski expedition to north-western Victoria, 1856-57. Proceedings of the Royal Society of Victoria 79: 371-391.

Wilson, B.A., Valentine, L.E., Reaveley, A., Isaac, J. and Wolfe, K.M. (2012). Terrestrial mammals of the Gnangara Groundwater System, Western Australia: history, status, and the possible impacts of a drying climate. Australian Mammalogy 34: 202-216.

Yassini, I. and Kendrick, G.W. (1988). Middle Holocene ostracodes, foraminifers and environments of beds at Point Waylen, Swan River Estuary, southwestern Australia. Alcheringa 12: 107-121.

MANUSCRIPT RECEIVED 1 JUNE 2017; ACCEPTED 30 NOVEMBER 2017. 
APPENDIX 1 Species guild designation references

TABLE A1 Grouping of non-volant mammal species into vegetation guilds according to the references below. These groupings were used for Figure 11.

\begin{tabular}{|c|c|c|c|c|c|}
\hline & Species & $\begin{array}{c}\text { Baynes } \\
1979\end{array}$ & $\begin{array}{l}\text { Dortch } \\
2004\end{array}$ & $\begin{array}{c}\text { Van Dyck \& Strahan } \\
2008\end{array}$ & $\begin{array}{l}\text { Adams et al. } \\
2016\end{array}$ \\
\hline \multirow{9}{*}{ 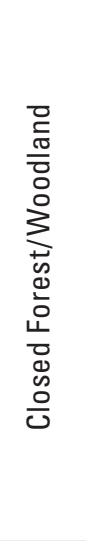 } & Antechinus flavipes & $\mathrm{x}$ & & $\mathrm{x}$ & $\mathrm{x}$ \\
\hline & Dasyurus geoffroii & $\mathrm{x}$ & & $\mathrm{x}$ & \\
\hline & Phascogale tapoatafa & $\mathrm{x}$ & & $\mathrm{x}$ & $\mathrm{x}$ \\
\hline & Sarcophilus harrisii & $\mathrm{x}$ & & $\mathrm{x}$ & $\mathrm{x}$ \\
\hline & Isoodon obesulus & $\mathrm{x}$ & & $\mathrm{x}$ & $\mathrm{x}$ \\
\hline & Trichosurus vulpecula & $\mathrm{x}$ & & $\mathrm{x}$ & $\mathrm{x}$ \\
\hline & Potorous platyops & & & $\mathrm{x}$ & $\mathrm{x}$ \\
\hline & Setonix brachyurus & $\mathrm{x}$ & $\mathrm{x}$ & $\mathrm{x}$ & \\
\hline & Pseudocheirus occidentalis & $\mathrm{x}$ & & $\mathrm{x}$ & \\
\hline \multirow{5}{*}{ 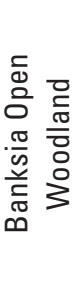 } & Parantechinus apicalis & $\mathrm{x}$ & & $\mathrm{x}$ & \\
\hline & Phascogale calura & $\mathrm{x}$ & & $\mathrm{x}$ & \\
\hline & Bettongia penicillata & $\mathrm{x}$ & & $\mathrm{x}$ & $\mathrm{x}$ \\
\hline & Cercartetus concinnus & $\mathrm{x}$ & & $\mathrm{x}$ & $\mathrm{x}$ \\
\hline & Pseudomys occidentalis & $\mathrm{x}$ & & $\mathrm{x}$ & $\mathrm{x}$ \\
\hline \multirow{12}{*}{ 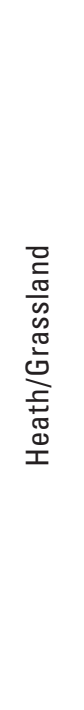 } & Perameles bougainville & $\mathrm{x}$ & $\mathrm{x}$ & $\mathrm{x}$ & $\mathrm{x}$ \\
\hline & Bettongia lesueur & $\mathrm{x}$ & $\mathrm{x}$ & $\mathrm{x}$ & $\mathrm{x}$ \\
\hline & Lagorchestes hirsutus & $\mathrm{x}$ & & $\mathrm{x}$ & \\
\hline & Macropus eugenii & $\mathrm{x}$ & $\mathrm{x}$ & $\mathrm{x}$ & $\mathrm{x}$ \\
\hline & Macropus fuliginosus & $\mathrm{x}$ & & $\mathrm{x}$ & $\mathrm{x}$ \\
\hline & Macropus irma & $\mathrm{x}$ & & $\mathrm{x}$ & \\
\hline & Petrogale lateralis & $\mathrm{x}$ & $\mathrm{x}$ & $\mathrm{x}$ & \\
\hline & Notomys mitchellii & & & $\mathrm{x}$ & \\
\hline & Pseudomys albocinereus & $\mathrm{x}$ & & $\mathrm{x}$ & \\
\hline & Pseudomys fieldi & $\mathrm{x}$ & & $\mathrm{x}$ & \\
\hline & Pseudomys shortridgei & $\mathrm{x}$ & & $\mathrm{x}$ & $\mathrm{x}$ \\
\hline & Rattus tunneyi & $\mathrm{x}$ & & $\mathrm{x}$ & \\
\hline
\end{tabular}

\section{REFERENCES}

Adams, S.J., McDowell, M.C. and Prideaux, G.J. (2016). Understanding accumulation bias in the ecological interpretation of archaeological and palaeontological sites on Kangaroo Island, South Australia. Journal of Archaeological Science: Reports 7: 715-729.

Baynes, A. (1979). The analysis of a late Quaternary mammal fauna from Hastings Cave, Jurien. Unpublished PhD Thesis, University of Western Australia.
Dortch, J. (2004). Late Quaternary vegetation change and the extinction of Black-flanked Rock-wallaby (Petrogale lateralis) at Tunnel Cave, southwestern Australia. Palaeogeography, Palaeoclimatology, Palaeoecology 211: 185-204.

Van Dyck, S. and Strahan, R., (eds) (2008). The mammals of Australia. 3rd edition. Reed New Holland: Sydney. 
APPENDIX 2 Section of 'Stone heap end' and test pit

FIGURE A2 Section illustration of 'Stone heap end' and the centralised test pit, originally drawn by Duncan Merrilees, traced, digitised and labelled by Thorn. See Table 1 in the paper for details on how the stratigraphy was assigned into spits and units. The test pit shown below was added at the suggestion of Merrilees after review of Roe's notes on the excavation (Roe 1971).

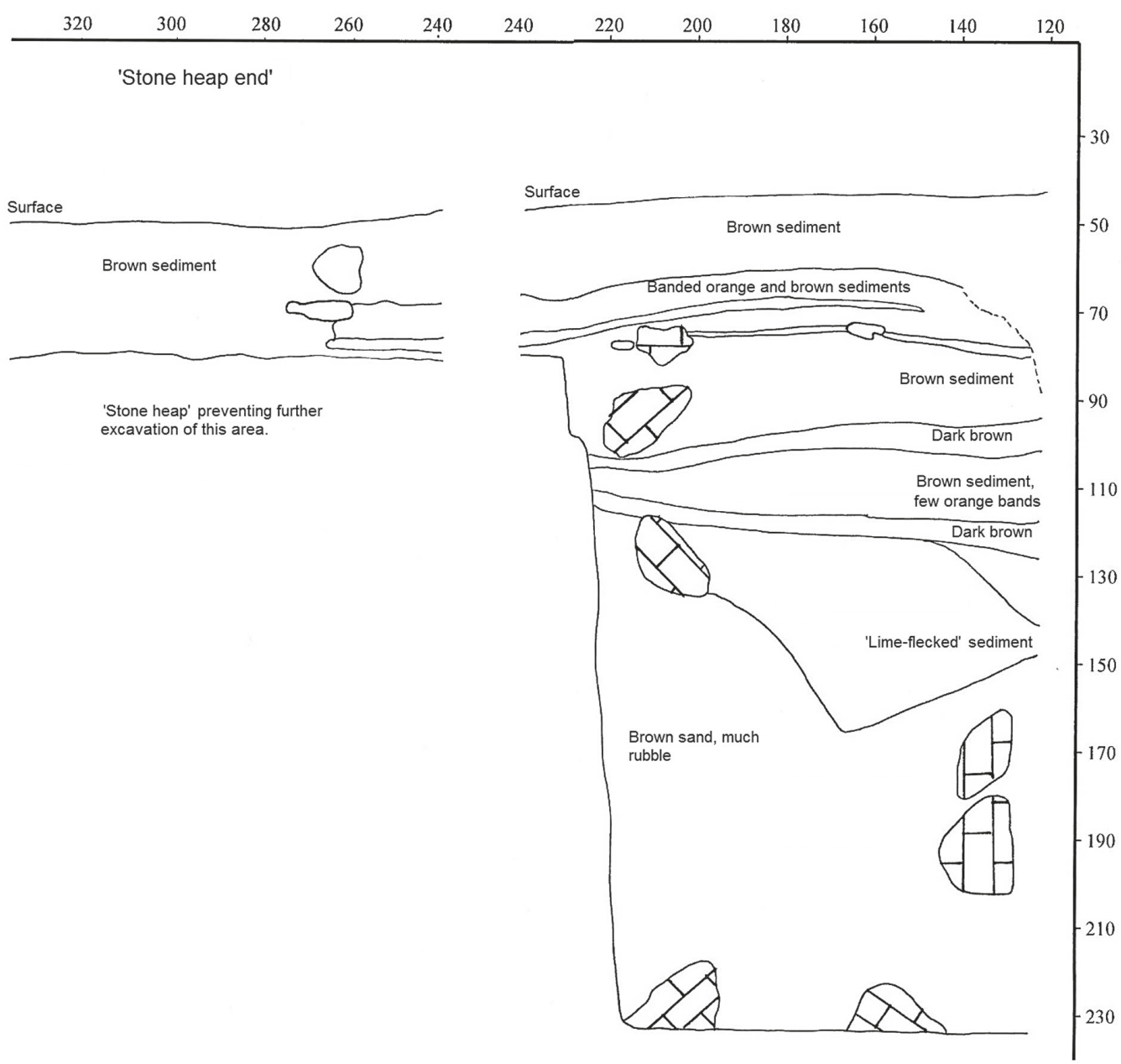

APPENDIX 3 Statistical tests for the taphonomic two size classes

TABLE A3.1 Shapiro-Wilk test for normality in the distribution of the digestion damage data within the two sizes.

\begin{tabular}{lll} 
& $<50 \mathrm{~g}$ & $>250 \mathrm{~g}$ \\
\hline $\mathrm{N}$ & 54 & 54 \\
Shapiro-Wilk W & 0.5919 & 0.9271 \\
\hline p(normal) & $5.25 \mathrm{E}-11$ & 0.002808
\end{tabular}

TABLE A3.2 Paired $t$-test to see if the $<50 \mathrm{~g}$ class and the $>250 \mathrm{~g}$ class show similar rates of digestion damage.

\begin{tabular}{|c|c|c|}
\hline & $<50 \mathrm{~g}$ & $>250 \mathrm{~g}$ \\
\hline $\mathrm{N}$ & 51 & \\
\hline Mean & 0.37255 & 2.6863 \\
\hline Median & 0 & 3 \\
\hline$t$-test & $-10.99 \quad p($ same $)$ & $6.06 \mathrm{E}-15$ \\
\hline
\end{tabular}

TABLE A3.3 Shapiro-Wilk test for normality of the bone breakage data within the two size classes, $<50 \mathrm{~g}$ and $>250 \mathrm{~g}$.

\begin{tabular}{lll} 
& $<50 \mathrm{~g}$ & $>250 \mathrm{~g}$ \\
\hline $\mathrm{N}$ & 54 & 54 \\
Shapiro-Wilk W & 0.864 & 0.8547 \\
\hline p(normal) & $2.02 \mathrm{E}-05$ & $1.08 \mathrm{E}-05$
\end{tabular}

TABLE A3.4 Paired t-test to see if the $<50 \mathrm{~g}$ class and the $>250$ g class show similar rates of bone breakage.

\begin{tabular}{|c|c|c|}
\hline & $<50 \mathrm{~g}$ & $>250 \mathrm{~g}$ \\
\hline $\mathrm{N}$ & 51 & \\
\hline Mean & 86.373 & 45.98 \\
\hline Median & 90 & 30 \\
\hline$t$-test & 7.848 & $2.86 \mathrm{E}-10$ \\
\hline
\end{tabular}


APPENDIX 4 FIGURES A4A-R Rarefaction graphs to test for sufficient sample size in each of the Groups (A-R) listed in Table 1.

A

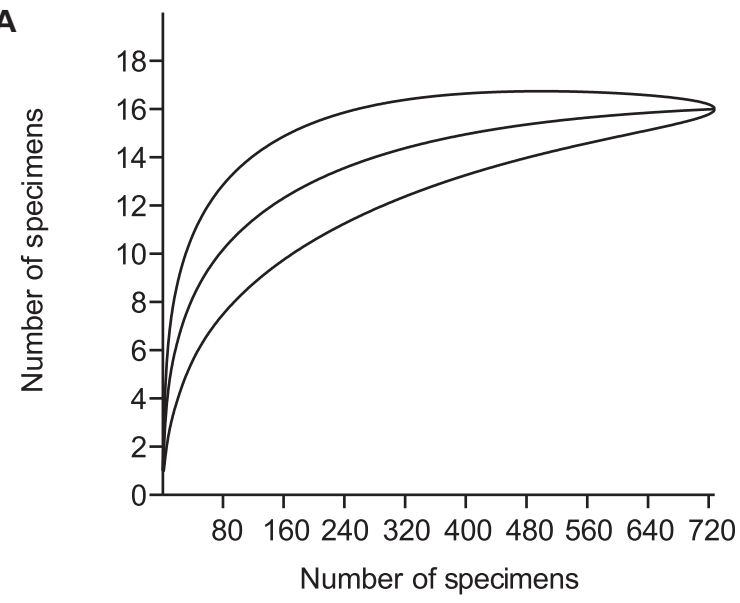

C

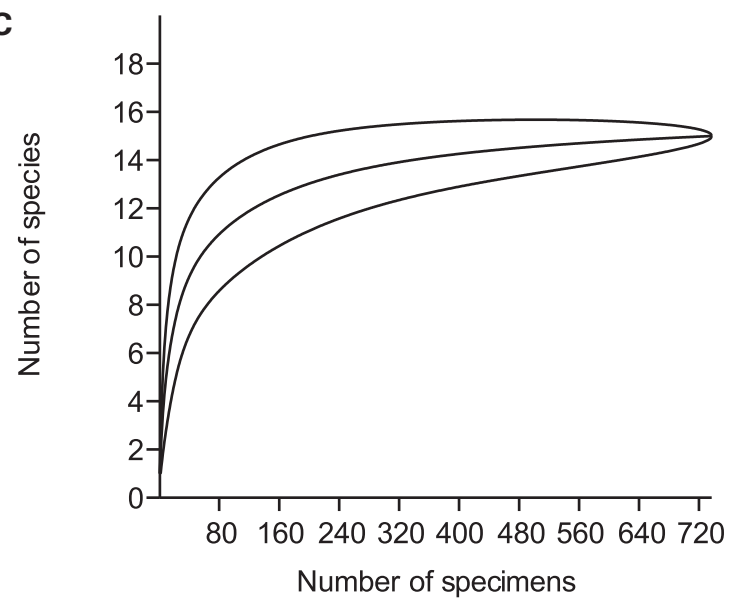

E

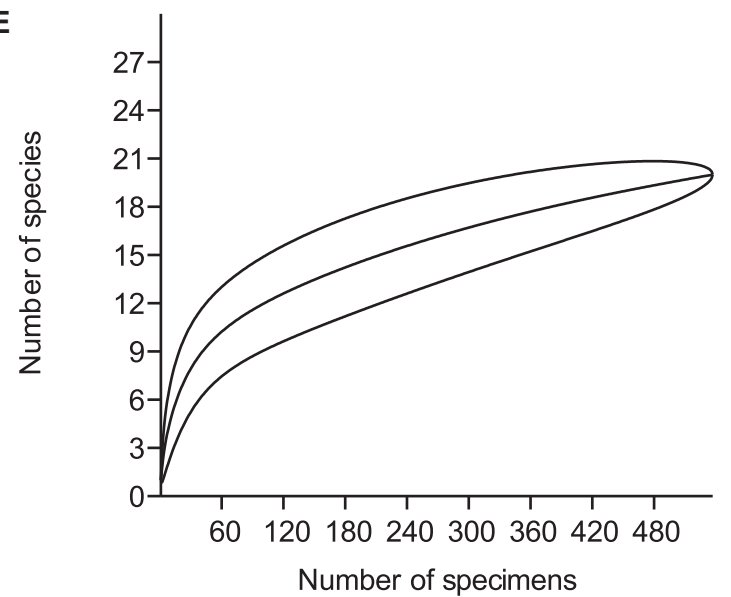

B

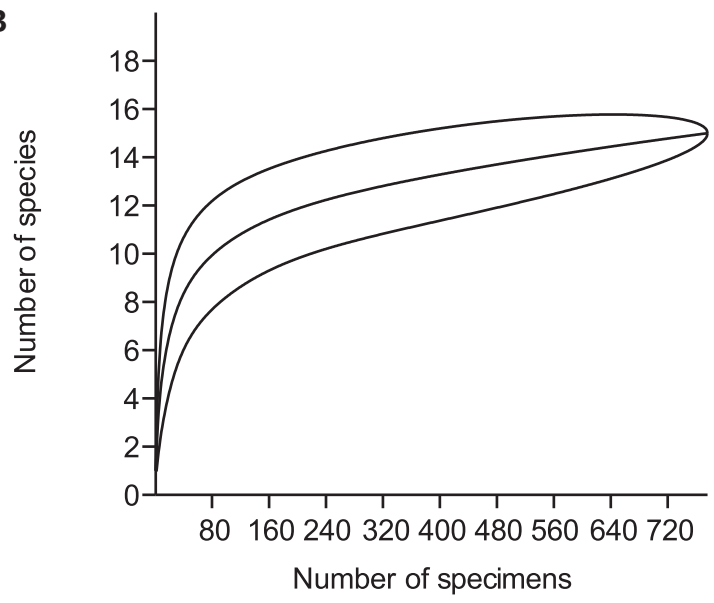

D

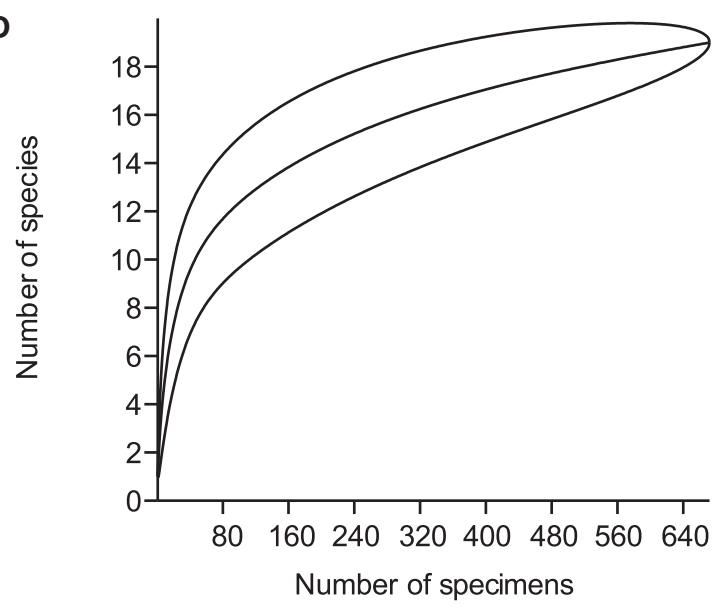

F

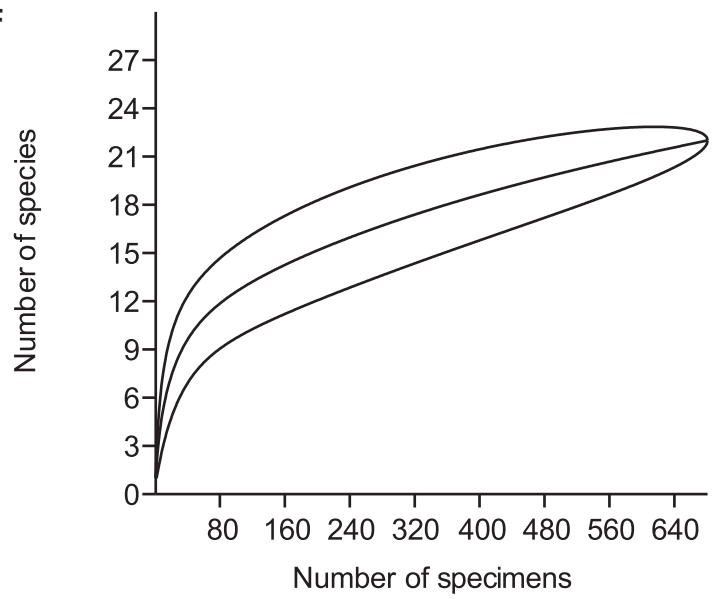



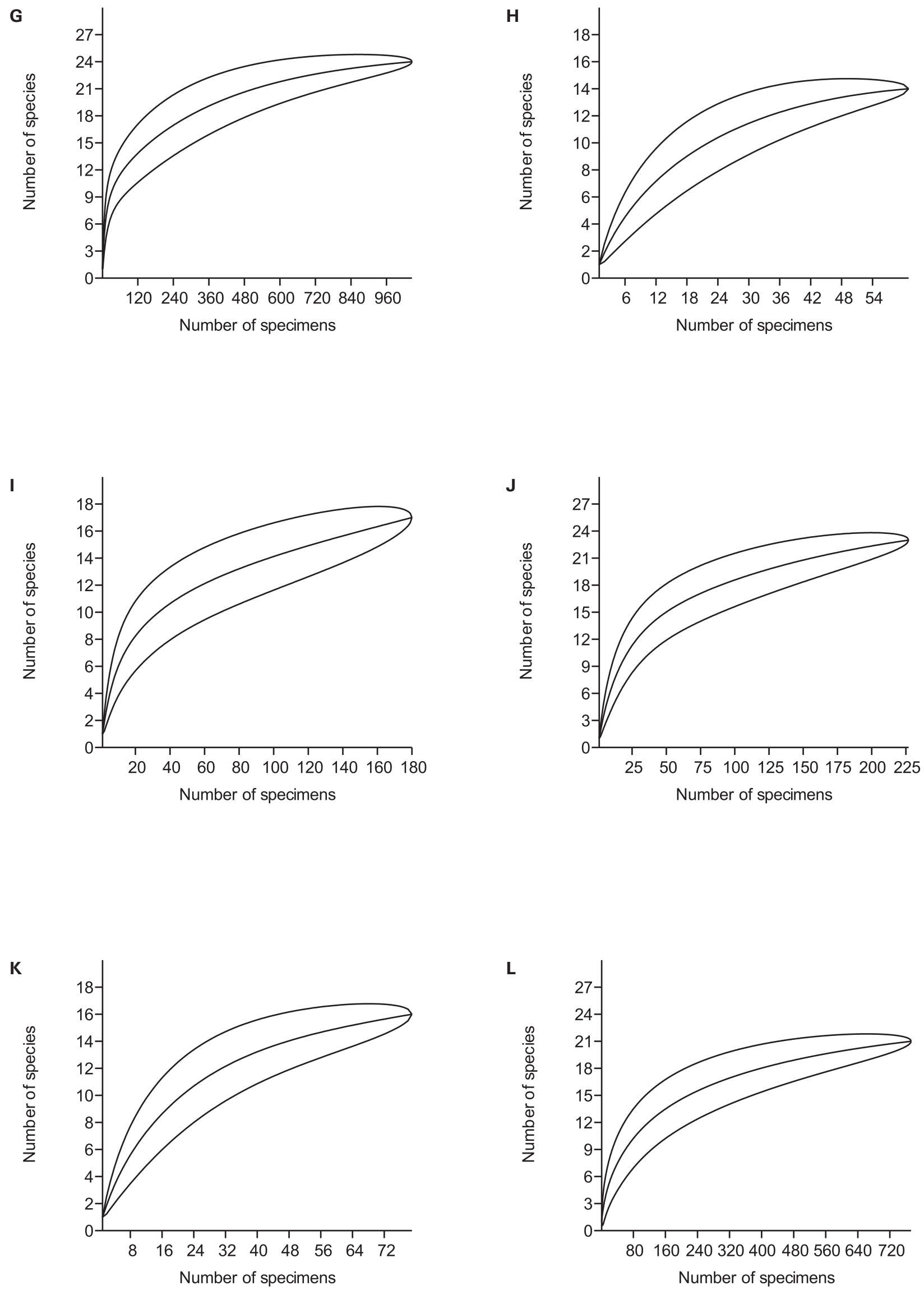

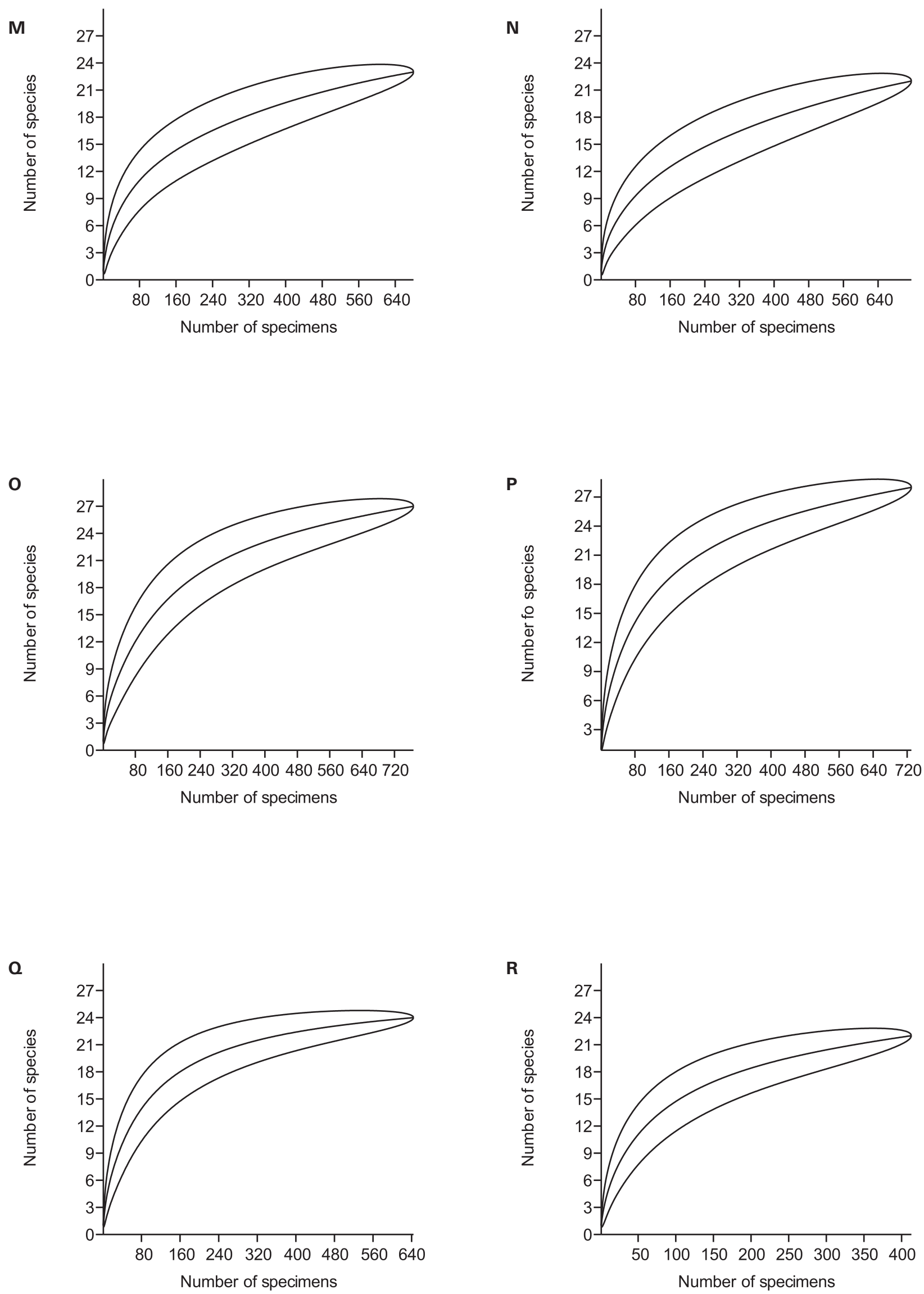